\title{
Comparison of quality changes in brined cabbage with deep sea water salt and a commercial brined cabbage product
}

\author{
Ji Hoon Lim¹, Jee Hee Jung ${ }^{1}$, Dong Soo Kim¹, Young Myoung Kim², Byoung Mok Kim* \\ ${ }^{1}$ Korea Food Research Institute, Gangneung 210-340, Korea \\ ${ }^{2}$ Korea Food Engineer Association, Seoul 137-863, Korea
}

\section{해양심층수염 절임배추와 시판 절임배추의 품질변화 비교}

\author{
임지훈 ${ }^{1} \cdot$ 정지희 $^{1} \cdot$ 김동수 $^{1} \cdot$ 김영명 $^{2} \cdot$ 김병목 $^{1 *}$ \\ ${ }^{1}$ 한국식품연구원, ${ }^{2}$ 한국식품기술사협회
}

\begin{abstract}
This study investigated the quality changes in cabbage brined with deep sea water salt and in a commercial brined cabbage product. The subject cabbages were separated into two groups: those manufactured in the Lab (ML) and the commercial brined cabbage product (CP). Each group had three brining treatments: with sun-dried salt (S, CS), refined salt $(\mathrm{R}, \mathrm{CR})$, and deep sea water salt $(\mathrm{D}, \mathrm{CD})$. The salinity level of the ML group was $2.1 \sim 2.3 \%$, higher than that of the CP group (1.1 1.5\%). The total plate count (TPC) was detected as $5.0 \mathrm{log}$ CFU/g with the $\mathrm{S}$, R, and D treatments at Day 7, but the growth rate of the TPC with the CS, CR, and CD treatments was faster than that with the $S, R$, and D treatments (6.9 7.7 $\log \mathrm{CFU} / \mathrm{g})$. A lactic acid bacteria (LAB) level of 5.0 6.6 $\log \mathrm{CFU} / \mathrm{g}$ was also detected in the $\mathrm{S}$, $\mathrm{R}$, and $\mathrm{D}$ samples, but only 7.0 7.6 log CFU/g was detected in the CP groups at Day 14. The instrumental hardness levels of the cabbage brined with the deep sea water salts (D and CD) were 3,971 $\mathrm{g}$ and $3,932.4 \mathrm{~g}$, respectively, which were significantly higher than those of the samples that were salted with sun-dried salt and refined salt $(p<0.05)$. As for the sensory attributes, $S$, D, and CD maintained their marketability scores until the end of the storage period for all the properties. CD presented the highest total free amino acid (478.9 mg\%), glutamic acid (107.0 mg\%), citric acid (428 mg\%), and sodium (189 ppm) contents.
\end{abstract}

Key words : cabbage, shelf-life, deep sea water salt

\section{서 론}

배추는 십자화과에 속하는 잎줄기 채소로서 우리나라 엽채류 생산량의 $50 \%$ 이상을 차지하는 주요 농작물 중 하나이며(1), 배추 생산량의 $90 \%$ 이상이 김치의 원료로 사 용된다(2). 김치는 배추를 소금에 절인 후 각종 채소와 양념 을 버무려 만드는 우리나라 전통식품으로서 세계 5대 건강 식품에 선정될 정도로 다양한 영양성분 및 기능성을 갖춘 식품이다 $(3,4)$. 김치의 제조공정 중 김치의 품질요소인 맛, 냄새, 조직감 등에 가장 깊은 연관성을 가지는 공정은 절임 공정으로 보고된 바 있다(5). 배추는 소금에 절여지는 과정 중 유해미생물의 성장을 억제, 호염성 미생물의 성장을 통 한 발효, 그리고 생배추에 비해 감소된 부피로 인한 유통비

*Corresponding author. E-mail : bmkim@kfri.re.kr

Phone : 82-33-643-8042, Fax : 82-33-643-8039
용의 절약효과도 볼 수 있다 $(6,7)$. 일반적으로 배추 절임시 천일염이나 정제염을 사용하나, 일부 지역에서는 해양심층 수염을 사용하는 경우도 있으며 지역에 따라 배추 절이는 방법이 조금씩 다르다(8). 천일염은 해수에서 수분을 증발 시켜 얻는 식용소금으로서 정제염에 비해 짠맛이 덜하고 무기질 함량이 풍부한 것으로 알려져 있으며, 정제염은 이 온교환막으로 염수를 제조한 후 수분을 증발시켜 제조한다 (9). 반면, 해양심층수염은 유기물의 농도가 낮고 대장균이 나 일반세균에 의한 오염이 거의 없으며, 육지나 대기로부 터의 화학물질에 의한 오염의 가능성도 거의 없는 청정한 해양심층수를 농축해서 얻어지는 것으로, 무기질 성분이 안정된 상태로 용해되어 있으며, 그 함량이 높아 식용으로 서의 연구가 활발히 진행 중이다 $(10,11)$. 또한, 해양심층수 염은 태양광이 도달하지 않고 식물성 플랑크톤이 없는 심해 에 존재하는 해양심층수로 제조하기 때문에 영양물질이 
풍부하고 칼슘이나 마그네슘 등 세포의 작용을 돕는 무기질 이 풍부히 포함되어 있다. 절임배추에 관한 연구로는 전해 산화수로 세척한 절임배추의 품질특성(12), 봄배추 재배방 법 및 품종에 따른 생육 및 절임특성(13), 포장방법을 달리 한 절임배추의 장기저장 중 품질변화(14), 시중 절임배추의 품질평가(15) 등 다양한 연구논문이 발표되고 있지만, 절임 시 사용되는 소금 종류에 따른 품질변화 및 해양심층수염을 이용한 절임배추의 품질특성, 또는 시판 절임배추와의 저 장 중 품질비교에 관한 연구는 미미한 실정이다. 천일염, 정제염 및 해양심층수염은 상이한 제조방법과 원료특성으 로 인해 염화나트륨의 함량 및 무기질 조성에 차이가 있어 각각의 소금으로 배추를 절일 경우 절임배추의 품질특성에 영향을 미칠 수 있다.

따라서 본 연구에서는 해양심층수염의 이용범위를 확대 하고 고부가가치 절임배추를 제조하고자 천일염, 정제염, 및 해양심층수염으로 절여진 절임배추의 냉장저장 중 이화 학적 및 관능적 품질특성을 비교 조사하였고, 절임소금의 종류별로 제조되어 판매중인 시판 절임배추와의 품질특성 을 함께 비교 조사하였다.

\section{재료 및 방법}

\section{실험재료}

본 실험에 사용된 배추는 2012년 전남 해남군에서 재배 된 겨울배추를 구입하여 사용하였으며, 개체 당 $2 \sim 2.5 \mathrm{~kg}$ 의 배추를 선별하여 절임용 원료로 사용하였다. 선별된 배추 는 밑둥을 직각으로 절단한 후 이물질을 제거하기 위해 흐르는 물로 1 분간 세척하였고, 세척을 마친 배추는 2 절하 여 실온에서 30 분간 자연탈수하였다. 절임용 소금은 정제 염(Hanju salt, Ulsan, Korea), 천일염(Shinan mineral salt, Shinan, Korea), 해양심층수염(deep sea water salt, Sokcho,Korea)을 각각 구매하여 사용하였으며, 시판 절임 배추는 제조일자는 동일하되 절임소금의 종류가 각기 다른 제품을 구입하여 사용하였다. 즉, 천일염 $(\mathrm{H}$ 사, Haenam, Korea), 정제염(H사, Seoul, Korea) 그리고 해양심층수염(S 사, Sokcho, Korea) 절임배추를 각각 구매하여 실험에 사용 하였다.

\section{배추절임}

자연탈수를 마친 배추는 정제염(R), 천일염 $(\mathrm{S})$ 및 해양심 층수염(D)을 이용하여 미리 제조해 둔 $12 \%$ 염수에 18 시간 절인 후 담수로 40 초간 세척, 20 초 탈수를 1 회로 하여 총 3 회 반복 세척하였다. 세척을 마친 배추는 1 시간 동안 실온 에서 자연 탈수한 후 polyethylene(PE) 재질의 지퍼백에 개 별 포장하였고, $0^{\circ} \mathrm{C}$ 로 설정된 저온실에 보관한 후 분석용 시료로 사용하였다. 시판제품의 경우 각 업체별로 제조공
정이 상이했다. 천일염 절임배추(CS)는 건염법으로서 절임 을 마친 후 담수로 세척하였으며, 정제염 절임배추(CR)는 $11 \%$ 의 염수에 15 시간 염장 후 담수로 세척, 탈수하였으며 해양심층수염 절임배추 $(\mathrm{CD})$ 는 $12 \%$ 의 염수에 10 시간 염장 후 담수로 세척한 것으로 조사되었다. 각 시판제품은 포장 개봉 후 $\mathrm{PE}$ 재질의 지퍼백에 개별포장하여 $0^{\circ} \mathrm{C}$ 로 설정된 저온실에 보관하면서 분석용 시료로 사용하였다.

\section{일반성분 분석}

일반성분은 $\mathrm{AOAC}$ 법(16)에 준하여 수분함량은 $105^{\circ} \mathrm{C}$ 상압가열건조법, 조단백질 함량은 semi-micro Kjeldahl법, 회분함량은 건식 회화법으로 측정하고, 조지방 함량은 soxthlet 추출법으로 분석하였으며, 측정치는 3회 반복하여 측정한 수치의 평균값으로 나타내었다.

\section{식염함량 분석}

식염함량은 Mohr법(17)에 의한 회화법으로서 염소정량 으로 분석되었다. 즉, 시료 $2 \sim 5 \mathrm{~g}$ 을 회화한 후 증류수로 $500 \mathrm{~mL}$ 정용하였고, Whatman No. 2를 이용하여 여과하였 다. 여과액 $10 \mathrm{~mL}$ 에 크롬산칼륨시약을 2 3방울 떨어뜨린 후 $0.02 \mathrm{~N} \mathrm{AgNO}_{3}$ 시약으로 미홍색이 나타나는 시점까지 적정하였고 이의 소비량을 계산하였다.

\section{$\mathrm{pH}$ 및 적정산도 측정}

$\mathrm{pH}$ 는 시료 $10 \mathrm{~g}$ 에 $90 \mathrm{~mL}$ 의 증류수를 가한 후 분쇄기(T 18 Ultra-Turrax, IKA, Königswinter, Germany)로 분쇄하여 상등액을 취하였고, $\mathrm{pH}$ meter(SG2-ELK, Mettler Toledo Co., Ltd., Switzerland)를 사용하여 측정하였다. 적정산도는 시료 $5 \mathrm{~g}$ 에 증류수 $45 \mathrm{~mL}$ 를 가한 후 교반하였고, 원심분리 하여 얻은 상등액 $10 \mathrm{~mL}$ 를 $0.1 \mathrm{~N} \mathrm{NaOH}$ 로 적정하여 $\mathrm{pH}$ 가 8.3 이 될 때까지의 소비량을 lactic acid 함량\%로 산출하였다.

\section{균체수 분석}

총균수는 $\mathrm{KFDA}$ 방법(18)에 따라 시료를 $10 \mathrm{~g}$ 채취하여 $90 \mathrm{~mL}$ 의 생리식염수에 넣고 균질기(BA 7020, Seward, UK) 로 2 분간 균질 한 후 상등액 $1 \mathrm{~mL}$ 를 취하여 $9 \mathrm{~mL}$ 의 생리식 염수가 들어 있는 시험관에 넣어 희석하였다. 여기서 다시 $0.1 \mathrm{~mL}$ 를 취하여 미리 준비한 배지(Standard- I nutrient agar, Merck, Germany)에 도말 한 후 $30^{\circ} \mathrm{C}$ 에서 48 시간 배양 하였으며, colony를 계수하여 $\log \mathrm{CFU} / \mathrm{g}$ 으로 계산하였다. 유산균은 PCA with BCP(bromocresol purple) with Tween $80\left(\mathrm{MB}\right.$ cell. Korea)를 사용하여 $37^{\circ} \mathrm{C}$ 에서 72 시간 배양한 후 colony를 계수하였다.

\section{물성 측정}

절임배추의 겉잎 부분 중 상대적으로 밝고 두께가 비슷 한 부위를 $3 \times 3 \mathrm{~cm}$ 의 크기로 절단하여 물성측정기(TA XT 
plus, Stable Micro System, England)로 경도와 씹힘성을 측 정하였다. 이 때 speed는 pre-test $3 \mathrm{~mm} / \mathrm{sec}$, test $1 \mathrm{~mm} / \mathrm{sec}$, post-test $1 \mathrm{~mm} / \mathrm{sec}$ 이였으며, 진입깊이는 $2 \mathrm{~mm}$, 시간은 2초, spindle은 shear force type을 사용하였다.

\section{무기질 분석}

무기질 분석은 저장 4 주차에 1 회 진행되었다. 시료 1 $\mathrm{g}$ 을 완전히 회화 시킨 후 질산용액과 염산용액을 이용하여 분해하였다. 분해를 마친 시료는 다시 회화한 후 증류수를 이용하여 $\mathrm{ppm}$ 단위로 희석하였다. 희석된 시료는 원자흡수 분광광도계(A analyst 700, Perkin Elmer, New York, NY, USA)로 정량분석 하였다.

\section{유리아미노산 분석}

유리아미노산은 시료 $2 \mathrm{~g}$ 을 채취하여 $50 \%$ ethanol 용액 $45 \mathrm{~mL}$ 을 가하여 3시간 동안 교반하였고 감압 농축기를 이용하여 에탄올을 제거하였다. 농축된 여액에 증류수를 가하여 $100 \mathrm{~mL}$ 로 정용한 다음 일부를 취하여 아미노산 자동분석기(L-8800, Hitachi, Tokyo, Japan)로 분석하였다. 이 때 컬럼은 ion exchange column(4.6 mm×60 mm), 오븐온 도는 $30 \sim 70^{\circ} \mathrm{C}$, 반응코일온도는 $135^{\circ} \mathrm{C}$ 이였으며, 유속은 분 당 $0.35 \mathrm{~mL}$ 이였다. 검출기는 $\mathrm{UV}$ detector를 사용하였고 검출파장은 $570 \mathrm{~nm}$ (channel 1)와 $440 \mathrm{~nm}$ (channel 2) 이었다.

\section{유기산 분석}

유기산은 동결건조 분말시료 $0.5 \mathrm{~g}$ 을 shaking incubator에 서 48 시간 동안 $85 \%$ ethanol $25 \mathrm{~mL}$ 로 추출한 후 원심분리하 고 상등액 $1 \mathrm{~mL}$ 를 취해 농축기(KR/AUTOSPIN 4080C, Hanil, Incheon, Korea)으로 농축한 다음 3차 증류수 200 $\mu \mathrm{L}$ 에 용해하였다. 이 용액을 0.0085 N H2SO4 $800 \mu \mathrm{L}$ 를 혼합하여 잘 섞은 후 원심분리 한 다음 상등액을 syringe filter(Whatman PVDF syringe filter $13 \mathrm{~mm}, 0.3 \mathrm{um}$ )로 여과 하여 HPLC 분석의 시료로 사용하였다. 유기산 분석에
이용된 HPLC의 구성은 Waters 515 HPLC pump, Waters 717 plus auto-sampler, Waters 486 Tunable Absorbance detector, Empower pro software 이였다. 유기산은 Grace Prevail organic Acid $5 \mu(150 \times 4.6 \mathrm{~mm})$ 분석용 column을 사용하여 분리하였으며, 이동상은 $25 \mathrm{mM}$ potassium phosphate $(\mathrm{pH}=2.5)$ 용액을 사용하였다. 시료는 $10 \mu \mathrm{L}$ 를 사 용하였고 검출기는 $\mathrm{UV}$ detector $\left(\lambda=210 \mathrm{~nm}, 25^{\circ} \mathrm{C}\right)$ 를 사용하 였다.

\section{관능적 기호도 조사}

28 60세 범위의 남녀 9명으로 패널을 구성하여 5점 평가 법(5점 : 매우 우수, 4점 : 우수, 3점 : 보통, 2점 : 나쁨, 1점 : 매우 나쁨)으로 관능적 산미, 외관, 그리고 전체적 기호도를 조사하였다. 이 때 외관은 저온실에서 시료를 꺼 낸 직 후 전체적인 외형을 평가하였으며, 산미는 절임배추 를 가로로 3절 후 밑둥 및 이파리가 제거 된 몸통 부분을 가로 $5 \mathrm{~cm}$, 세로 $5 \mathrm{~cm}$ 크기로 절단 후 평가시료로 사용하였 다.

\section{통계처리}

SPSS(18.0, SPSS Inc., Chicago, IL, USA) program을 이용 하여 Duncan's multiple range test로 유의수준 $\mathrm{p}<0.05$ 에서 유의성을 검증하였다.

\section{결과 및 고찰}

\section{일반성분}

절임소금의 종류에 따른 절임배추의 저장 0주차 일반성 분은 Table 1 과 같다. 수분함량은 $\mathrm{S}, \mathrm{R}, \mathrm{D}$ 구 각각 92.2 , $92.2,91.8 \%$ 로 D 구가 실험실 제조군 중 유의적으로 낮은 함량을 보였다. $\mathrm{CS}, \mathrm{CR}, \mathrm{CD}$ 구의 수분함량은 각각 93.5, 92.3, $93.1 \%$ 로서, $\mathrm{CS}$ 구가 실험군 중 유의적으로 가장 높았

Table 1. Proximate composition of salted-cabbages prepared by various types of salt on initial week.

(unit : \%)

\begin{tabular}{ccccccc}
\hline & \multicolumn{3}{c}{ Parameters } \\
\cline { 2 - 7 } Group & Moisture & Crude ash & $\begin{array}{c}\text { Crude } \\
\text { lipid }\end{array}$ & Crude protein & Carbohydrate & Salinity \\
\cline { 2 - 7 } & $92.2 \pm 0.12^{\mathrm{C} 2}$ & $2.5 \pm 0.11^{\mathrm{B}}$ & $1.5 \pm 0.12^{\mathrm{B}}$ & $0.2 \pm 0.0^{\mathrm{C}}$ & $3.6 \pm 0.21^{\mathrm{C}}$ & $2.5 \pm 0.05^{\mathrm{B}}$ \\
S & $92.2 \pm 0.11^{\mathrm{C}}$ & $2.6 \pm 0.21^{\mathrm{AB}}$ & $1.4 \pm 0.11^{\mathrm{B}}$ & $0.2 \pm 0.0^{\mathrm{C}}$ & $3.8 \pm 0.23^{\mathrm{A}}$ & $2.6 \pm 0.20^{\mathrm{A}}$ \\
R & $91.8 \pm 0.21^{\mathrm{D}}$ & $2.7 \pm 0.31^{\mathrm{A}}$ & $1.5 \pm 0.32^{\mathrm{B}}$ & $0.3 \pm 0.0^{\mathrm{B}}$ & $3.7 \pm 0.15^{\mathrm{B}}$ & $2.5 \pm 0.06^{\mathrm{B}}$ \\
CS & $93.5 \pm 0.22^{\mathrm{A}}$ & $1.8 \pm 0.12^{\mathrm{C}}$ & $1.5 \pm 0.24^{\mathrm{B}}$ & $0.4 \pm 0.0^{\mathrm{A}}$ & $3.3 \pm 0.12^{\mathrm{E}}$ & $1.8 \pm 0.12^{\mathrm{C}}$ \\
CR & $92.3 \pm 0.12^{\mathrm{C}}$ & $1.9 \pm 0.13^{\mathrm{C}}$ & $1.9 \pm 0.14^{\mathrm{A}}$ & $0.2 \pm 0.0^{\mathrm{C}}$ & $3.7 \pm 0.16^{\mathrm{B}}$ & $1.7 \pm 0.07^{\mathrm{D}}$ \\
CD & $93.1 \pm 0.21^{\mathrm{B}}$ & $1.5 \pm 0.11^{\mathrm{D}}$ & $1.8 \pm 0.20^{\mathrm{A}}$ & $0.2 \pm 0.0^{\mathrm{C}}$ & $3.4 \pm 0.16^{\mathrm{D}}$ & $1.1 \pm 0.04^{\mathrm{E}}$ \\
\hline
\end{tabular}

${ }^{11)} \mathrm{S}$ : cabbage brined with sun dried salt; $\mathrm{R}$ : cabbage brined with refined salt; D : cabbage brined with deep sea water salt; CS : purchased cabbage brined with sun dried salt; $\mathrm{CR}$ : purchased cabbage brined with refined salt; $\mathrm{CD}$ : purchased cabbage brined with deep sea water salt

${ }^{2}$ Means with different letters (A-F) between the different treatments differ significantly $(\mathrm{p}<0.05)$. 
으며, 다음으로 $\mathrm{CD}$ 구가 높았다. 회분함량은 실험실 제조군 인 $\mathrm{S}, \mathrm{R}$ 및 $\mathrm{D}$ 구가 각각 $2.5 \%, 2.6 \%, 2.7 \%$ 로 나타났으며 $\mathrm{D}$ 구가 $\mathrm{S}$ 와 $\mathrm{R}$ 구에 비해 유의적으로 높았다( $\mathrm{p}<0.05)$. 시판 제품군인 $\mathrm{CS}, \mathrm{CR}$, 및 $\mathrm{CD}$ 구의 회분함량은 $2 \%$ 미만이었다. 조지방 함량은 $\mathrm{CR}$ 과 $\mathrm{CD}$ 구가 실험군들 중 가장 많은 $1.9 \%$ 와 $1.8 \%$ 였으며, S, D 및 CS 구는 모두 $1.5 \%$ 이었다. R 구의 조지방 함량은 $1.4 \%$ 로서 실험군 중 가장 낮았지만, 통계적 유의차는 확인되지 않았다( $>>0.05)$. 조단백질 함량은 $\mathrm{CS}$ 구가 $0.4 \%$ 로 실험군 중 가장 높았으며, 다음으로 D 구가 $0.3 \%$ 이였다. $\mathrm{S}, \mathrm{R}, \mathrm{CR}$ 및 $\mathrm{CD}$ 구의 조단백질 함량은 모두 $0.2 \%$ 이었다. 탄수화물 함량은 R, D 및 CR 구가 각각 $3.8 \%$, $3.7 \%$, 및 $3.7 \%$ 로 R 구가 실험군 중 가장 높았으며 $(\mathrm{p}<0.05)$, $\mathrm{S}$ 구는 이보다 유의적으로 낮은 $3.6 \%$ 이었다. 식염함량은 실험실 제조군인 $\mathrm{S}, \mathrm{R}$ 및 $\mathrm{D}$ 구에서 $2.5 \%, 2.6 \%$, 그리고 $2.5 \%$ 로 측정되었고, $\mathrm{CS}, \mathrm{CR}$ 및 $\mathrm{CD}$ 구의 식염함량은 각각 $1.8 \%, 1.7 \%, 1.1 \%$ 로 나타나 실험실 제조군에 비해 유의적으 로 낮은 함량을 보였다 $(\mathrm{p}<0.05)$. 시판제품군의 경우 실험실 제조군에 비해 식염함량이 낮은 것은 절임배추로 김장을 할 때 액젓 등의 부재료를 통해 염도가 높아질 수 있기에 초기염도를 낮게 설정했을 것으로 사료되었다.

\section{수분함량}

절임소금의 종류에 따른 절임배추의 $0^{\circ} \mathrm{C}$ 저장 중 수분함 량의 변화는 Fig. 1 과 같다. S 구의 수분함량은 저장 0 주차에 $92.2 \%$ 이였으나, 저장 1 주차에는 $92.6 \%$ 로 증가하였지만 저장 2주차부터는 감소하기 시작하여 저장 4주차에는 $90.8 \%$ 까지 하락하였다 $(\mathrm{p}<0.05) . \mathrm{R}$ 구의 수분함량 역시 저장 1 주차에는 $92.3 \%$ 로 저장 0 주차에 비해 소폭 증가하였으나 통계적 유의차는 확인되지 않았고, 저장 2주차부터 점차적

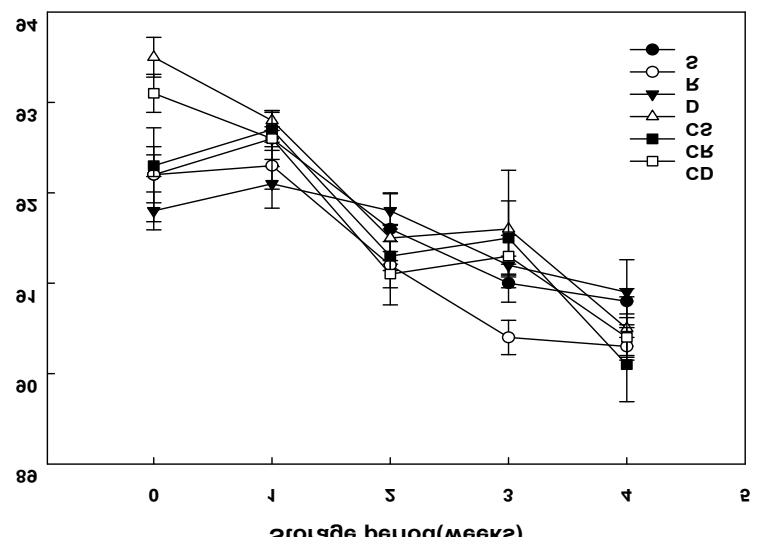

Fig. 1. Changes in moisture content of salted-cabbages prepared by various types of salt during the storage period.

; cabbage brined with sun dried salt, $\bigcirc$; cabbage brined with refined salt, $\nabla$ cabbage brined with deep sea water salt, $\triangle$; purchased cabbage brined with sun dried salt, $\square$; purchased cabbage brined with refined salt, $\square$; purchased cabbage brined with deep sea water salt. The expression level is presented as means (bar) with standard deviation (error bar). Significant differences between untreated and treated were determined using a Duncan's test $(\mathrm{p}<0.05)$.
으로 감소하기 시작하여 저장 4주차에는 $90.3 \%$ 로 확인되었 다. D 구의 수분함량은 저장 0주차에 $91.8 \%$, 저장 1 주차에 는 $92.1 \%$ 로 나타나 소폭 증가하였으며 $(\mathrm{p}<0.05)$ 저장기간이 경과함에 따라 점차 감소하여 저장 4주차에는 $90.9 \%$ 로 확 인되었다 $(\mathrm{p}>0.05)$. 실험실제조군의 수분함량의 경우, 저장 1 주차까지는 해양심층수염 절임배추인 $\mathrm{D}$ 구의 수분함량이 천일염이나 정제염 절임배추에 비해 유의적으로 낮았지만, 저장 2 주차부터는 $\mathrm{D}$ 구의 수분함량이 $\mathrm{S}$ 구와 $\mathrm{R}$ 구에 비해 높은 수준을 보였다 $(\mathrm{P}<0.05) . \mathrm{CS}$ 구의 수분함량은 저장 0 주 차에 $93.5 \%$ 이였으며, 저장기간이 경과함에 따라 감소하여 저장 4 주차에는 $90.5 \%$ 로 확인되었다. $\mathrm{CR}$ 구의 수분함량은 저장 0 주차에는 $92.3 \%$ 이였고, 저장 1 주차에는 $92.7 \%$, 저장 2주차에는 $91.3 \%$ 로 하락하였으며 저장 3주차에는 $91.5 \%$, 저장 4 주차에는 $90.1 \%$ 로 확인되었다. $\mathrm{CD}$ 구의 수분함량은 저장기간이 경과함에 따라 유의적으로 감소하였는데, 저장 0 주차에는 $93.1 \%$ 이였으나 저장 2주차에는 $91.1 \%$, 저장 4주차에는 $90.4 \%$ 로 확인되었다. 또한 저장 0 주차에는 실험 실 제조군의 수분함량이 시판제품군에 비해 낮은 수분함량 을 보였지만, 저장 4주차에는 실험실 제조군의 수분함량이 유의적으로 높은 것으로 확인되었다. 이처럼 절임배추의 수분함량이 저장기간이 증가함에 따라 감소하는 것은 소금 이 배추 조직내로 흡수되면서 삼투작용에 의해 배추 조직내 의 수분이 탈수됨에 따라 약간의 수분함량 감소현상을 보인 것으로 여겨지며, 저장 4주차에 실험실 제조군이 시판제품 군에 비해 높은 수분함량을 보인 것은 원료배추의 품질차이 일 것으로 사료되었다. 또한 저장 4주차에 실험실제조군과 시판제품군에서 모두 정제염으로 절여진 $\mathrm{R}$ 구와 $\mathrm{CR}$ 구의 수분함량이 낮은 수준을 보였다.

\section{식염함량}

절임소금의 종류에 따른 절임배추의 $0^{\circ} \mathrm{C}$ 저장 중 식염함 량의 변화는 Fig. 2에 나타내었다. 저장 0주차의 식염함량은 $\mathrm{S}, \mathrm{R}, \mathrm{D}$ 구가 각각 $2.5 \%, 2.6 \%, 2.5 \%$ 이였고, $\mathrm{CS}, \mathrm{CR}, \mathrm{CD}$ 구의 식염함량은 $1.8 \%, 1.7 \%, 1.1 \%$ 로 각각 나타나 $\mathrm{CS}, \mathrm{CR}$, $\mathrm{CD}$ 구의 식염함량이 유의적으로 낮았다. $\mathrm{S}$ 구의 경우 저장 기간이 경과함에 따라 유의적인 경향을 보이며 감소하였는 데, 저장 0 주차에는 $2.5 \%$ 이었고 저장 4 주차에는 $2.2 \%$ 까지 하락하였다 $(\mathrm{p}<0.05) . \mathrm{R}$ 구의 경우 저장 1 주차와 2 주차에 각각 $2.5 \%$ 와 $2.3 \%$ 로 저장기간이 경과함에 따라 유의적으 로 감소하였고, 저장 4 주차에는 $2.0 \%$ 로 나타났다. D 구는 저장 1 주차에 $2.5 \%$ 로 저장 초기와 같았지만, 저장 2 주차에 는 $2.4 \%$ 로 나타나 저장 1 주차에 비해 다소 감소하였으며, 저장 3 주차와 4 주차에는 모두 $2.3 \%$ 로 최종 확인되었다. $\mathrm{CS}$ 구는 저장 1 주차에 $1.7 \%$, 저장 2 주차와 3 주차에는 모두 $1.6 \%$ 로 나타나 저장기간이 경과함에 따라 유의적으로 감소 하였으며, 저장 4 주차에는 $1.4 \%$ 로 나타났다 $(\mathrm{p}<0.05) . \mathrm{CR}$ 구는 저장 1 주차에 $1.5 \%$ 로 저장 0 주차에 비해 $0.2 \%$ 정도 


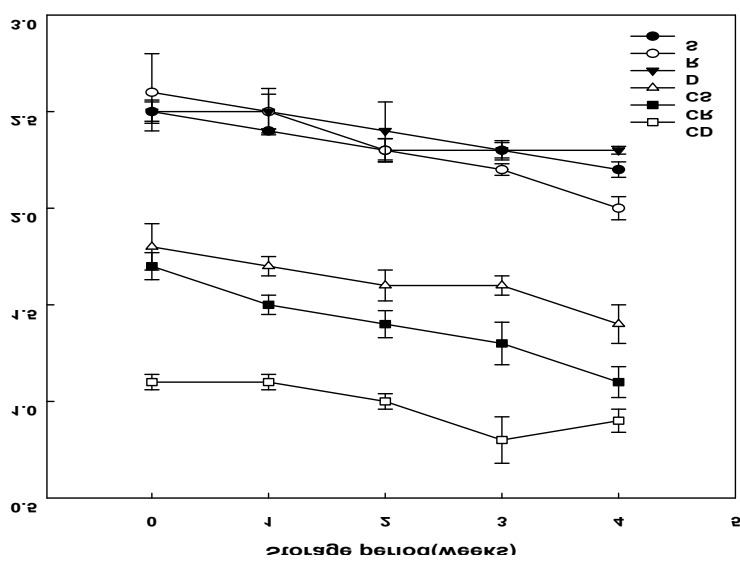

Fig. 2. Changes in salt content of salted-cabbages prepared by various types of salt during the storage period.

; cabbage brined with sun dried salt, $\bigcirc$; cabbage brined with refined salt, $\nabla$ cabbage brined with deep sea water salt, $\triangle$; purchased cabbage brined with sun dried salt, $\square$; purchased cabbage brined with refined salt, $\square$; purchased cabbage brined with deep sea water salt. The expression level is presented as means (bar) with standard deviation (error bar). Significant differences between untreated and treated were determined using a Duncan's test $(p<0.05)$

감소하였고 저장기간이 경과함에 따라 감소하여 저장 4주 차에는 $1.1 \%$ 까지 하락하였다. $\mathrm{CD}$ 구의 경우저장 1 주차에 $1.1 \%$ 로 저장 0 주차에 비해 변화가 없었지만, 저장 2 주차부 터는 소폭 감소하였고 저장 3 주차에는 $0.8 \%$ 로 나타나 실험 군 중 가장 낮은 함량을 보였다. 실험실 제조군과 시판제품 군 모두, 정제염 절임배추인 $\mathrm{R}$ 구와 $\mathrm{CR}$ 구의 식염함량 감소 가 심한 것으로 나타났으며, 이에 대헤서는 추가적인 연구 가 필요할 것으로 사료되었다. 본 연구에서 $\mathrm{CS}, \mathrm{CR}, \mathrm{CD}$ 구의 저장 0 주차 식염함량은 $1.1 \sim 1.8 \%$ 이었는데 $\mathrm{Kim}$ 등(15) 은 시중에 판매중인 절임배추들의 식염함량이 $0.5 \sim 2.0 \%$ 수준이었다고 보고하여 본 연구와 유사한 결과를 보였다. $\mathrm{Kim}$ 등(19)은 절임배추가 발효초기와 비교하였을 때 후기 로 갈수록 약간 증가하거나 감소하며 발효기간에 따른 염도 의 차이는 크지 않았다고 보고하였는데, 본 연구에서는 저 장기간이 경과함에 따라 다소 감소하는 경향을 보였다. Han 등(14)은 $\mathrm{LDPE}$ 필름에 절임배추를 저장 했을 때 액에 잠긴 아랫부분의 배추는 염도변화가 없었지만, 액에 잠기지 않 은 윗부분의 배추들은 저장기간이 경과함에 따라 염도가 하락했다고 하였으며 $\mathrm{Kim}$ 등(20)은 절임염수의 농도 및 포장재에 따라 절임배추를 저장했을 때 $0,5 \%$ 의 염수에 절여진 배추는 저장기간이 경과함에 따라 식염함량에 변화 가 없었지만, $10 \%$ 염수에 절여진 배추들은 통계적 유의차 는 나타나지 않았지만 저장기간이 경고함에 따라 식염함량 이 감소하였으며, 특히 high density polyethylene(HDPE) 필 름에 포장 된 절임배추의 감소가 크다고 하였다. 따라서 본 연구에서는 탈수 후 개별포장한 절임배추가 저장기간이 경과함에 따라 추가적으로 탈수가 진행되었으며, 이 때 염 분도 함께 빠져 나왔을 것으로 사료되었다.
$\mathrm{pH}$ 및 적정산도

절임소금의 종류에 따른 절임배추의 $0^{\circ} \mathrm{C}$ 저장 중 $\mathrm{pH}$ 변화 는 Fig. 3과 같다. 모든 실험군의 저장 0 주차 $\mathrm{pH}$ 는 6.0 6.2 수준으로 나타나 Lee 등(21)이 보고한 6.0과 Park 등(22)이 보고한 5.9보다는 다소 높게 나타났다. 저장 0 주차 $\mathrm{pH}$ 는 $\mathrm{S}, \mathrm{R}, \mathrm{CS}$ 및 $\mathrm{CD}$ 구 모두 6.2로 나타나 다른 실험군에 비해 유의적으로 높은 값을 보였다. $\mathrm{S}$ 구는 저장 1 3주차에 모두 6.3 으로 나타나 저장 0 주차에 비해 증가하였지만, 저장 4 주 차에는 6.2로 확인되었다. $\mathrm{R}$ 구의 $\mathrm{pH}$ 는 저장 0 주차 6.2에서 저장 1 주차에 6.5 로 증가하였으나 저장 2 주차와 3 주차에는 모두 6.4로 나타났고, 저장 4주차에는 6.1로 나타났다. D 구는 저장 1 주차에 6.5 로 저장 0 주차에 비해 상승하였으나 이 후 점차 감소하여 저장 4주차에는 실험실 제조군 중 가장 낮은 5.8로 확인되었다. 실험실 제조군의 경우 천일염 절임배추인 $\mathrm{S}$ 구는 저장기간 전반적으로 $6.2 \sim 6.3$ 의 $\mathrm{pH}$ 값을 보여, $\mathrm{pH}$ 값의 큰 변화는 없는 것으로 나타났지만, $\mathrm{R}$ 구와 $\mathrm{D}$ 구는 각각 $6.5 \sim 6.1,6.5 \sim 5.8$ 로 천일염 절임배추에 비해 $\mathrm{pH}$ 의 변화폭이 큰 것으로 조사되었다. $\mathrm{CS}$ 구는 저장 1 주차 에 6.0 , 저장 2 주차에는 5.5 로 저장기간이 경과함에 따라 감소하였고, 저장 4 주차에는 5.1로 감소하였다. CR 구는 저장기간이 경과함에 따라 유의적으로 감소하였고, 저장 4주차에는 5.0로 나타났다 $(\mathrm{p}<0.05) . \mathrm{CD}$ 구는 저장기간이 경과함에 따라 점차 감소하여 저장 4주차에는 5.1로 나타났 다( $\mathrm{p}<0.05) \cdot \mathrm{pH}$ 측정 결과, 저장말기에 가까워질수록 $\mathrm{CS}$ $\mathrm{CR}, \mathrm{CD}$ 구가 $\mathrm{S}, \mathrm{R}, \mathrm{D}$ 구에 비해 $\mathrm{pH}$ 하락이 빠른 것으로 나타났는데, 이는 실험실 제조군에 비해 낮은 염도 때문에 유산균 이외에도 기타 미생물의 증식이 용이했으며, 이로 인해 발생 된 여러 대사산물에 의해 $\mathrm{pH}$ 값이 빠르게 하락했 을 것으로 사료되었다. 또한 모든 실험군에서 저장기간이

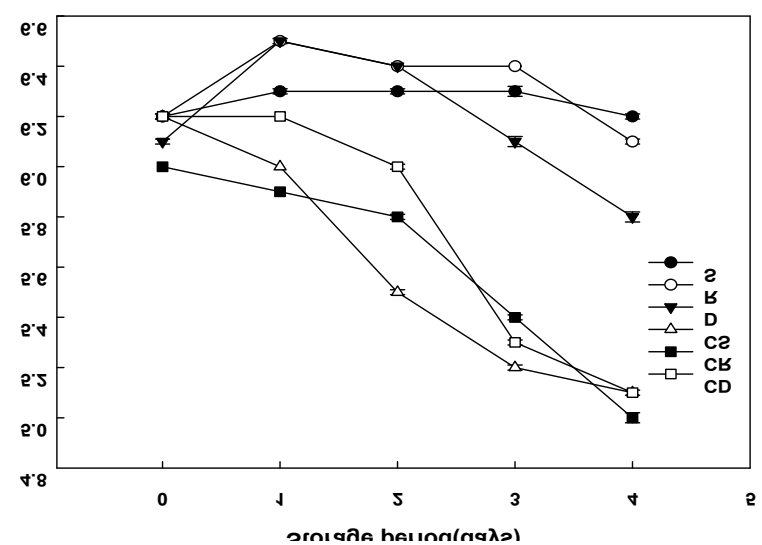

Fig. 3. Changes in $\mathrm{pH}$ values of salted-cabbages prepared by various types of salt during the storage period.

; cabbage brined with sun dried salt, $\bigcirc$; cabbage brined with refined salt, $\nabla$ cabbage brined with deep sea water salt, $\triangle$; purchased cabbage brined with sun dried salt, $\square$; purchased cabbage brined with refined salt, $\square$; purchased cabbage brined with deep sea water salt. The expression level is presented as means (bar) with standard deviation (error bar). Significant differences between untreated and treated were determined using a Duncan's test $(\mathrm{p}<0.05)$ 
경과함에 따라 $\mathrm{pH}$ 가 감소하였는데 이는 효소와 미생물이 탄수화물이나 당을 분해함으로써 생성되는 유기산에 의해 $\mathrm{pH}$ 의 감소가 나타난 것으로 여겨진다(23). Kim 등(6)은 절 임염수의 염도가 높을수록 절임배추의 저장 시 $\mathrm{pH}$ 의 하락 이 안정적으로 유지되었으며, $\mathrm{pH}$ 를 6.0 이상으로 유지할 수 있다면 상품성에 문제가 없을 것이라고 하였다. 본 연구 에서도 $\mathrm{S}, \mathrm{R}, \mathrm{D}$ 구의 $\mathrm{pH}$ 가 저장 28 일까지 6.1 6.2로 나타나 $\mathrm{CS}, \mathrm{CR}, \mathrm{CD}$ 구에 비해 유의적으로 높게 나타났고 해양심층 수염으로 제조한 절임배추(D)의 경우에도 저장기간 중 $\mathrm{pH}$ 의 증감이 나타났으나 $\mathrm{CS}, \mathrm{CR}, \mathrm{CD}$ 구에 비해 유의적으로 높은 $\mathrm{pH}$ 를 보여 $\mathrm{Kim}$ 등(6)의 보고에서처럼 상품성에 문제 는 없을 것으로 사료되었다.

절임소금의 종류에 따른 절임배추의 $0^{\circ} \mathrm{C}$ 저장 중 적정산 도의 변화는 Fig. 4 와 같다. 저장 0 주차에 산도값은 $\mathrm{S}$ 와 $\mathrm{R}$ 구가 각각 0.34 와 $0.35 \%$ 로 나타나 실험군 중 가장 높은 값을 보여, $\mathrm{S}, \mathrm{R}, \mathrm{D}$ 구(0.3\%)가 $\mathrm{CS}, \mathrm{CR}, \mathrm{CD}$ 구(0.2\%)에 비해 다소 높게 나타난 것으로 관찰되었으나, 저장 1 주차 $\mathrm{S}, \mathrm{R}, \mathrm{CR}, \mathrm{CD}$ 구의 산도값은 0.47 0.48\%로 나타나 실험군 간의 통계적 유의차는 없는 것으로 조사되었다 $(\mathrm{p}<0.05)$. 저 장 2주차 적정산도는 $\mathrm{S}$ 와 $\mathrm{CS}$ 구 모두 $0.57 \%$ 로 실험군 중 가장 높았고, $\mathrm{R}$ 구와 $\mathrm{CR}$ 구 각각 0.53 과 $0.52 \%$ 로서 통계 적으로 낮은 수준을 보였다 $(\mathrm{p}<0.05)$. 저장 3 주차에는 $\mathrm{R}$ 구 와 $\mathrm{CS}$ 구 모두 $0.64 \%$ 로 실험군 중 가장 높았고 $\mathrm{D}$ 구가 $0.60 \%$ 로 가장 낮았다. 저장 4 주차에는 $\mathrm{S}, \mathrm{R}, \mathrm{D}$ 구와 $\mathrm{CS}$, $\mathrm{CR}, \mathrm{CD}$ 구 사이에 큰 차이를 보였는데, $\mathrm{S}, \mathrm{R}, \mathrm{D}$ 구의 경우 $0.61 \sim 0.65 \%$ 의 값을 보인 반면, $\mathrm{CS}, \mathrm{CR}, \mathrm{CD}$ 구는 $0.71 \sim 0.78 \%$ 로 나타나 S, R, D 구에 비해 유의적으로 높은 산도값을 보였다 $(\mathrm{p}<0.05)$. 또한 해양심층수염으로 제조한 절임배추(D)의 적정산도가 저장 4 주차에 $0.61 \%$ 로 나타나

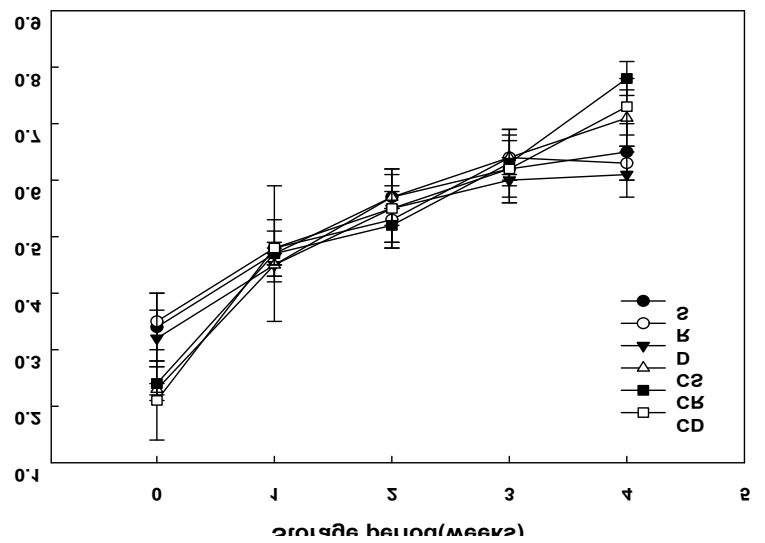

Fig. 4. Changes in titratable acidity values of salted-cabbages prepared by various types of salt during the storage period.

; cabbage brined with sun dried salt, $\bigcirc$; cabbage brined with refined salt, $\nabla$ cabbage brined with deep sea water salt, $\triangle$; purchased cabbage brined with sun dried salt, $\square$; purchased cabbage brined with refined salt, $\square$; purchased cabbage brined with deep sea water salt. The expression level is presented as means (bar) with standard deviation (error bar). Significant differences between untreated and treated were determined using a Duncan's test $(\mathrm{p}<0.05)$.
실험군 중 가장 낮은 값을 보였다. $\mathrm{CS}, \mathrm{CR}, \mathrm{CD}$ 구의 산도가 $\mathrm{S}, \mathrm{R}, \mathrm{D}$ 구의 산도에 비해 유의적으로 높게 나타난 것은 저장 1 주 이후부터 $\mathrm{CS}, \mathrm{CR}, \mathrm{CD}$ 구에서의 젖산균 증식이 빠르게 나타나 $\mathrm{pH}$ 의 감소에 영향을 미쳤고, 효소와 미생물 에 의해 유기산 생성이 높아져 $\mathrm{pH}$ 가 감소하여 적정산도값 이 증가하였기 때문인 것으로 여겨진다.

\section{균체수}

절임소금의 종류에 따른 절임배추의 $0^{\circ} \mathrm{C}$ 저장 중 총균수 의 변화는 Fig. 5 와 같다. 저장 0 주차 총균수는 $\mathrm{CS}$ 구와 $\mathrm{CR}$ 구에서 각각 4.8 과 $4.7 \log \mathrm{CFU} / \mathrm{g}$ 으로 나타나 실험군 중 유의적으로 많은 균이 검출되었다 $(\mathrm{p}<0.05) . \mathrm{S}$ 구와 $\mathrm{R}$ 구는 모두 $4.5 \log \mathrm{CFU} / \mathrm{g}, \mathrm{D}$ 구는 $4.3 \log \mathrm{CFU} / \mathrm{g}$ 이 검출되어 저장 0 주차 $1 \mathrm{~g}$ 당 총균수가 $4.0 \log \mathrm{CFU} / \mathrm{g}$ 정도였다는 $\mathrm{Han}$ 등(24)의 결과보다는 적은 총균이 검출되었다. 그러나 $\mathrm{Kim}$ 등(15)은 시판제품을 수거하여 미생물을 분석한 결과, 최저 $3.37 \log \mathrm{CFU} / \mathrm{g}$ 에서 최고 $6.05 \log \mathrm{CFU} / \mathrm{g}$ 의 총균이 검출되 었다고 보고한 바 있어 본 연구의 결과와 유사하였다. S 구의 총균수는 저장 1주차에 $5.1 \log \mathrm{CFU} / \mathrm{g}$, 저장 3주차에는 $6.9 \log \mathrm{CFU} / \mathrm{g}$ 이 검출되어 저장기간이 경과함에 따라 유의 적으로 증가하였으며 저장 28 일에는 $7.2 \log \mathrm{CFU} / \mathrm{g}$ 로 확인 되었다 $(\mathrm{p}<0.05) . \mathrm{R}$ 구는 저장 1 주차에 $4.0 \mathrm{log} \mathrm{CFU} / \mathrm{g}$, 저장 2주차에는 $5.4 \log \mathrm{CFU} / \mathrm{g}$ 로 나타나 실험군 중 유의적으로 적은 수의 균이 검출되었고 저장 3주차에는 $7.1 \log \mathrm{CFU} / \mathrm{g}$ 로 급격히 증가하였으며, 저장 4주차에는 $7.3 \log \mathrm{CFU} / \mathrm{g}$ 으 로 확인되었다. D 구는 저장 2주차에 $6.5 \log \mathrm{CFU} / \mathrm{g}$, 저장 4주차에는 $7.3 \log \mathrm{CFU} / \mathrm{g}$ 으로 각각 확인되었다. 저장 0주차 와 1 주차에는 $\mathrm{D}$ 구가 $\mathrm{S}$ 구나 $\mathrm{R}$ 구에 비해 유의적으로 적은 수의 균이 검출되었지만(p<0.05), 저장 3 주차 이 후에는

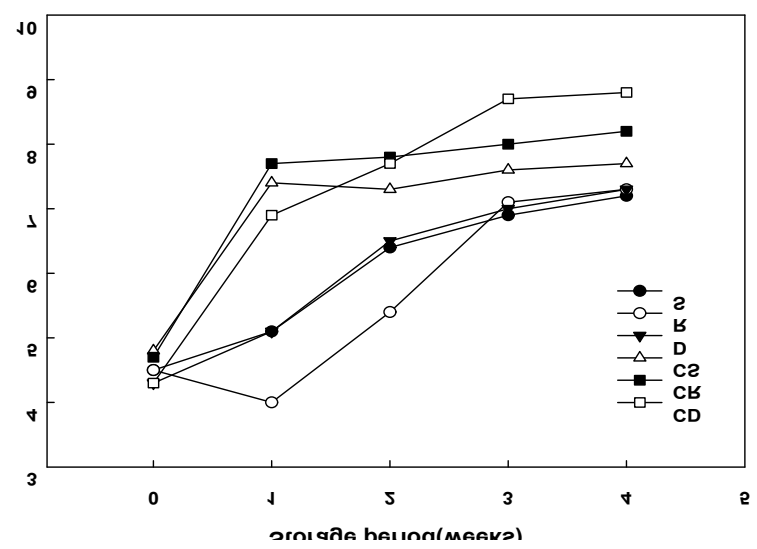

Fig. 5. Changes in total aerobe bacteria counts of salted-cabbages prepared by various types of salt during the storage period.

; cabbage brined with sun dried salt, $\bigcirc$; cabbage brined with refined salt, $\nabla$ cabbage brined with deep sea water salt, $\triangle$; purchased cabbage brined with sun dried salt, $\square$; purchased cabbage brined with refined salt, $\square$; purchased cabbage brined with deep sea water salt. The expression level is presented as means (bar) with standard deviation (error bar). Significant differences between untreated and treated were determined using a Duncan's test $(\mathrm{p}<0.05)$. 
실험실 제조구간 통계적 유의차는 확인되지 않았다 (p>0.05). CS 구의 총균수는 저장 0주차에 $4.8 \mathrm{log} \mathrm{CFU} / \mathrm{g}$ 으 로 나타나 실험군 중 가장 많은 총균이 검출되었고, 저장 3 주차에는 $7.6 \log \mathrm{CFU} / \mathrm{g}$ 로 증가하였다. $\mathrm{CR}$ 구는 저장 1주 차에 $7.7 \log \mathrm{CFU} / \mathrm{g}$ 이 검출되어 초기에 비해 빠르게 증식하 였으며 저장 2주차에는 $7.8 \log \mathrm{CFU} / \mathrm{g}$, 저장 3주차와 4주차 에는 각각 8.0 과 $8.2 \log \mathrm{CFU} / \mathrm{g}$ 이 검출되어 총균의 증식률은 낮아졌지만 저장기간이 경과함에 따라 유의적으로 증가하 였다. $\mathrm{CD}$ 구는 저장 1 주차에 $6.9 \log \mathrm{CFU} / \mathrm{g}, 2$ 주차에는 $7.7 \log \mathrm{CFU} / \mathrm{g}$ 까지 증가하였고 저장 3주차와 4주차에는 각각 8.7 과 $8.8 \log \mathrm{CFU} / \mathrm{g}$ 이 검출되어 저장기간이 경과함에 따라 유의적으로 증가하였다. 총균수의 경우 저장 0 주차에 $\mathrm{CS}, \mathrm{CR}, \mathrm{CD}$ 구가 $\mathrm{S}, \mathrm{R}, \mathrm{D}$ 구에 비해 증식속도가 빠른 것으로 나타났으며, $\mathrm{CS}, \mathrm{CR}, \mathrm{CD}$ 구들은 저장 말기에도 $\mathrm{S}, \mathrm{R}, \mathrm{D}$ 구에 비해 유의적으로 많은 총균이 검출되었다 $(\mathrm{p}<0.05)$. 한 편 $\mathrm{CR}$ 구에서만 붉은색 미생물이 성장하여 가식이 불가할 것으로 사료되었는데(25), 이는 총균수가 $7 \log \mathrm{CFU} / \mathrm{g}$ 이상 이 되면 절임배추의 변질이 상당히 진행되어 상품으로서 가치가 없다는 Jeong 등(26)의 보고와 유사하였다.

절임소금의 종류에 따른 절임배추의 $0^{\circ} \mathrm{C}$ 저장 중 유산균 수 변화는 Fig. 6과 같다. 저장 0 주차에는 $\mathrm{CD}$ 구에서 5.0 $\log \mathrm{CFU} / \mathrm{g}$ 검출되어 실험군 중 가장 많은 유산균이 검출되 었고 $\mathrm{S}, \mathrm{R}, \mathrm{D}$ 구들은 각각 $4.0,4.1,3.9 \log \mathrm{CFU} / \mathrm{g}$ 으로 $\mathrm{CS}$, $\mathrm{CR}, \mathrm{CD}$ 구에 비해 유의적으로 적은 수의 유산균이 검출되 었다. $\mathrm{S}$ 구는 저장 1 주차에는 $5.0 \log \mathrm{CFU} / \mathrm{g}$ 이었으나 저장 4주차에는 $7.2 \log \mathrm{CFU} / \mathrm{g}$ 까지 성장한 것으로 확인되었다. $\mathrm{R}$ 구는 저장 1 주차에 $4.6 \log \mathrm{CFU} / \mathrm{g}$, 저장 2주차에는 5.0 $\log \mathrm{CFU} / \mathrm{g}$ 의 유산균이 검출되어 실험군 중 가장 적은 균이 검출되었으나 이후 급격히 증가하여 저장 3 주차에는 7.0

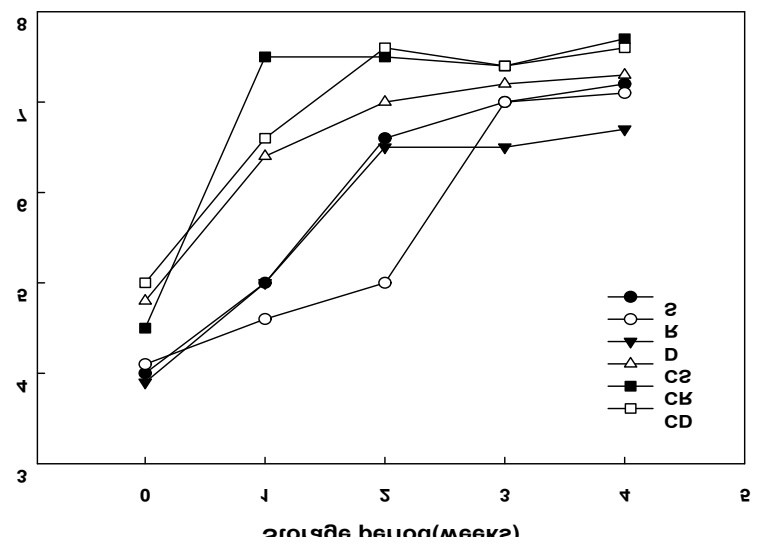

Fig. 6. Changes in lactic acid bacteria counts of salted-cabbages prepared by various types of salt during the storage period.

; cabbage brined with sun dried salt, $\bigcirc$; cabbage brined with refined salt, $\nabla$; cabbage brined with deep sea water salt, $\triangle$; purchased cabbage brined with sun dried salt, $\square$; purchased cabbage brined with refined salt, $\square$; purchased cabbage brined with deep sea water salt. The expression level is presented as means (bar) with standard deviation (error bar). Significant differences between untreated and treated were determined using a Duncan's test $(\mathrm{p}<0.05)$. $\log \mathrm{CFU} / \mathrm{g}$, 저장 4주차에는 $7.1 \log \mathrm{CFU} / \mathrm{g}$ 으로 최종 확인되 었다. D 구는 저장 1 주차에 $5.0 \log \mathrm{CFU} / \mathrm{g}$, 저장 2주차와 3 주차에는 모두 $6.5 \log \mathrm{CFU} / \mathrm{g}$ 의 유산균이 검출되었고 저장 4주차에는 $6.7 \log \mathrm{CFU} / \mathrm{g}$ 이 검출되었다 $(\mathrm{p}<0.05) . \mathrm{CS}$ 구는 저장 1 주차에 $6.4 \log \mathrm{CFU} / \mathrm{g}$ 이 검출되어 $\mathrm{S}, \mathrm{R}, \mathrm{D}$ 구에 비해 빠른 증식을 보였고, 저장 2주차에는 $7.0 \log \mathrm{CFU} / \mathrm{g}$ 저장 3 주차와 4주차에 각각 7.2 와 $7.3 \log \mathrm{CFU} / \mathrm{g}$ 으로 확인되었다. $\mathrm{CR}$ 구는 저장 1 주차에 $7.5 \log \mathrm{CFU} / \mathrm{g}$ 이 검출되어 실험군 중 가장 많은 유산균이 검출되었고 저장 3주차에는 $7.4 \mathrm{log}$ $\mathrm{CFU} / \mathrm{g}$, 저장 4주차에는 $7.7 \log \mathrm{CFU} / \mathrm{g}$ 으로 증가하였다 (p<0.05). $\mathrm{CD}$ 구는 저장 1 주차에 $6.6 \log \mathrm{CFU} / \mathrm{g}$, 저장 2주차 에는 $7.6 \log \mathrm{CFU} / \mathrm{g}$, 저장 3주차와 4주차에 각각 7.4와 7.6 $\log \mathrm{CFU} / \mathrm{g}$ 의 유산균이 검출되어 2 주차에 비해 유산균의 성장률은 크게 변화가 없는 것으로 나타났다.

\section{물성}

절임소금의 종류에 따른 절임배추의 $0^{\circ} \mathrm{C}$ 저장 중 경도 변화는 Fig. 7과 같다. 저장 0주차 경도는 S, R, D 구들 각각 7824.1, 8341.1, 7711.9 $\mathrm{g}$ 였으며, $\mathrm{CS}, \mathrm{CR}, \mathrm{CD}$ 구들은 각각 $8013.7,7420.0,8270.9 \mathrm{~g}$ 로 나타났으며, 통계적 유의차 는 확인되지 않았다(p>0.05). S 구의 경우 저장 0주차 7824.1 $\mathrm{g}$ 이였고 저장 1 주차에는 $5104.1 \mathrm{~g}$, 저장 4주차에는 3782.2 $\mathrm{g}$ 로 각각 나타나 저장기간이 경과함에 따라 감소하였다. $\mathrm{R}$ 구는 저장 1 주차에 $5570.4 \mathrm{~g}$ 이었으나 저장 4주차에 $3077.4 \mathrm{~g}$ 으로 나타나 저장기간이 경과함에 따라 유의적으 로 감소하였다. $\mathrm{D}$ 구는 저장 0 주차 $7711.9 \mathrm{~g}$ 이였다가 저장 1 주차에는 $6535.6 \mathrm{~g}$ 저장 2주차에는 $5620.0 \mathrm{~g}$ 저장 4주차에 는 $3971.9 \mathrm{~g}$ 로 최종 확인되었다. CS 구는 저장 0주차 8013.7 $\mathrm{g}$ 이였고 저장 4주차에는 $2821.7 \mathrm{~g}$ 로 나타나 실험군 중

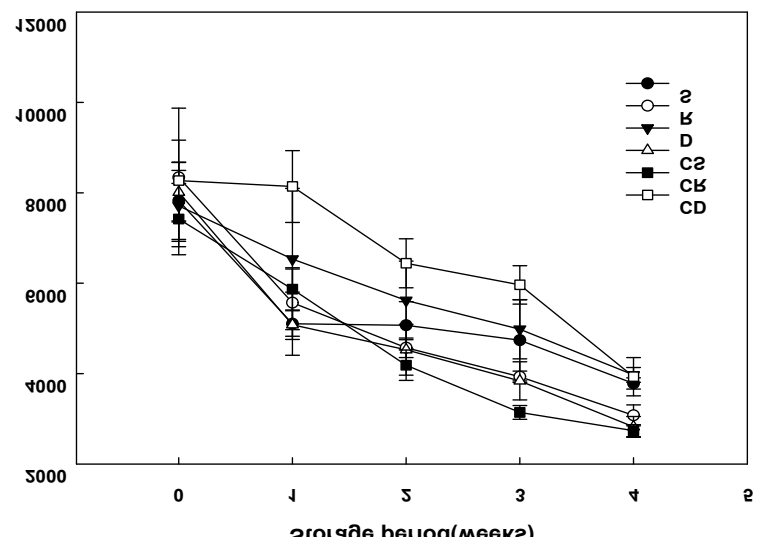

Fig. 7. Changes in hardness of salted-cabbages prepared by various types of salt during the storage period.

; cabbage brined with sun dried salt, $\bigcirc$; cabbage brined with refined salt, $\nabla$; cabbage brined with deep sea water salt, $\triangle$; purchased cabbage brined with sun dried salt, $\square$; purchased cabbage brined with refined salt, $\square$; purchased cabbage brined with deep sea water salt. The expression level is presented as means (bar) with standard deviation (error bar). Significant differences between untreated and treated were determined using a Duncan's test $(\mathrm{p}<0.05)$ 
가장 낮은 경도를 보인 것으로 확인되었다. $\mathrm{CD}$ 구는 저장 1 주차에 $8139.7 \mathrm{~g}$, 저장 2주차에는 $6440.5 \mathrm{~g}$, 저장 4주차에는 $3932.4 \mathrm{~g}$ 로 나타나 저장기간이 경과함에 따라 유의적으로 감소하였다. 경도의 경우 해양심층수염으로 절여진 $\mathrm{D}$ 와 $\mathrm{CD}$ 구가 저장기간이 경과함에 따라 감소하였으나, 그 감소 폭이 다른 실험군에 비해 낮았으며, 저장기간 전반에 걸쳐 천일염이나 정제염으로 절임한 절임배추들에 비해 높은 경도값을 보였다. Lee 등(27)은 배추절임 시 소금농도가 높을수록 경도가 떨어진다고 하였는데, 본 연구에서는 상 대적으로 식염함량이 낮은 $\mathrm{CS}, \mathrm{CR}, \mathrm{CD}$ 구와 $\mathrm{S}, \mathrm{R}, \mathrm{D}$ 구 사이에서 큰 차이는 없었고, 경도와 염도간의 유의적 차이 는 확인할 수는 없었다. 다만 무를 해양심층수염과 천일염 으로 절였을 때 염장시간이 길어질수록 해양심층수염 절임 무의 젤리강도가 천일염에 비해 높았다는 Lee 등(28)의 보 고와 같이 저장 말기 경도는 해양심층수염으로 절인 $\mathrm{D}$ 와 $\mathrm{CD}$ 구가 높게 나타났다.

절임소금의 종류에 따른 절임배추의 $0^{\circ} \mathrm{C}$ 저장 중 씹힘성 변화는 Fig. 8과 같다. S 구는 저장 초기 5816.4였으나 저장 1 주차에는 5947.6, 저장 2주차에는 5203.9로 감소하였고 저장 4주차에는 1084.6 으로 최종 확인되었다. $\mathrm{R}$ 구는 저장 0 주차 6081.4였으나 저장 1주차에는 4608.2, 저장 4주차에 는 906.7로 나타났다. D 구는 저장 0주차 5713.0이었으나 저장 2 주차에는 3843.4 , 저장 4 주차에는 1054.8 로 하락하였 다. $\mathrm{CS}$ 구는 저장 0 주차 6124.8 이었으나 저장 1 주차에는 6698.7, 저장 2주차에는 5048.3, 저장 3주차에는 5228.6, 4주 차에는 1438.4로 확인되었다. $\mathrm{CR}$ 구는 저장 0주차 5416.7로 시판 제품군 중 가장 낮았고 저장기간이 경과함에 따라 유의적으로 감소하여 저장 4주차에는 785.5로 나타나 실험 군 중 가장 낮았다. $\mathrm{CD}$ 구는 저장 0 주차 6557.1로 실험군

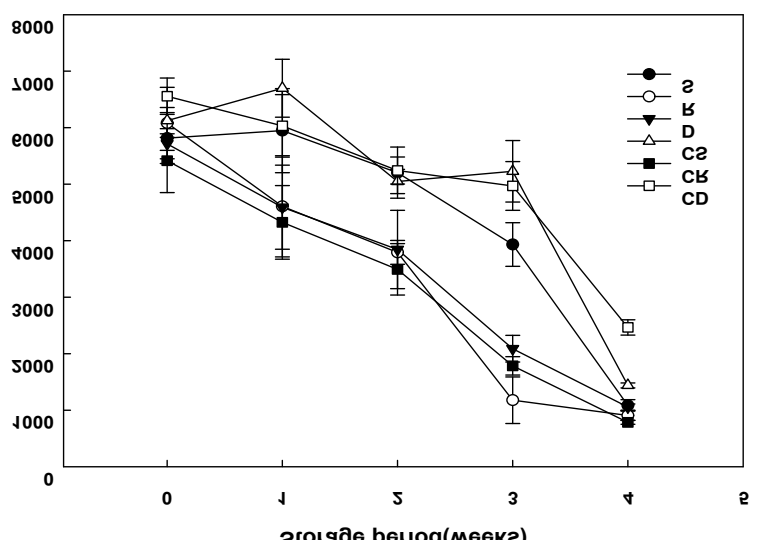

Fig. 8. Changes in chewiness of salted-cabbages prepared by various types of salt during the storage period.

; cabbage brined with sun dried salt, $\bigcirc$; cabbage brined with refined salt, $\nabla$ cabbage brined with deep sea water salt, $\triangle$; purchased cabbage brined with sun dried salt, $\square$; purchased cabbage brined with refined salt, $\square$; purchased cabbage brined with deep sea water salt. The expression level is presented as means (bar) with standard deviation (error bar). Significant differences between untreated and treated were determined using a Duncan's test $(\mathrm{p}<0.05)$.
중 가장 높았으며, 저장 4주차에는 2464.7로 확인되었다 (p<0.05). 씹힘성 실험 결과 $\mathrm{S}, \mathrm{CS}, \mathrm{CD}$ 구들이 저장 2주차까 지 5000 이상의 값을 유지했으나 R 과 $\mathrm{CR}$ 구는 저장 3 주차 에 각각 $1176.7,1785.5$ 로 다른 실험군에 비해 상대적으로 낮은 씹힘성을 보였다. 모든 실험군에서 저장기간이 경과 할수록 경도 및 씹힘성이 감소하는 것은 배추 조직의 연화 가 진행되었기 때문에 기인된 것으로 사료되며, 절임배추 조직으로부터 수분 손실 및 미생물의 증식 등에 의해 저장 중 절임배추의 탄력성이 감소하였다는 $\mathrm{Kim}$ 등(29)의 보고 와 유사한 결과를 보였다.

\section{관능평가}

절임에 사용한 소금의 종류에 따른 절임배추의 $0^{\circ} \mathrm{C}$ 저장 중 관능적 외관 변화는 Table 5와 같다. 관능적 외관은 저장 0 주차에는 모든 실험군에서 모두 5.0점으로 우수한 평가를 받았으나 저장기간이 경과함에 따라 유의적으로 감소하였 고 저장 4 주차에는 $\mathrm{S}, \mathrm{R}, \mathrm{D}$ 구가 각각 $3.2,3.2,3.3$ 점으로 $\mathrm{CS}, \mathrm{CR}, \mathrm{CD}$ 군에 비해 유의적으로 높은 평가를 받았다. $\mathrm{CR}$, $\mathrm{CD}$ 구의 경우 저장 2 주차부터 $\mathrm{S}, \mathrm{R}, \mathrm{D}, \mathrm{CS}$ 구에 비해 유의적 으로 낮은 평가를 받았던 반면, $\mathrm{D}$ 구는 저장 기간 중 다른 실험군에 비해 유의적으로 높은 평가를 유지하였다. 절임 소금의 종류에 따른 절임배추의 $0^{\circ} \mathrm{C}$ 저장 중 관능적 산미 변화는 Table 6과 같다. 관능적 산미는 저장기간이 경과함 에 따라 유의적으로 감소하였는데 $\mathrm{S}, \mathrm{R}, \mathrm{D}$ 구의 산미가 저장 3주차부터 낮은 평가를 받은 반면 $\mathrm{CS}, \mathrm{CR}, \mathrm{CD}$ 구는 저장 2주차부터 낮은 평가를 받았으며, 특히 D 구의 산미 기호도가 저장기간 동안 다른 실험군에 비해 높은 평가를 받았다. 절임소금의 종류에 따른 절임배추의 $0^{\circ} \mathrm{C}$ 저장 중 전체적 기호도 변화는 Table 7과 같다. 전체적 기호도는 저장기간이 경과함에 따라 유의적으로 감소하였는데, $\mathrm{S}$, $\mathrm{R}, \mathrm{D}$ 구의 전체적인 기호도가 저장 3 주차부터 낮은 평가를 받은 반면 $\mathrm{CS}, \mathrm{CR}, \mathrm{CD}$ 구는 저장 2 주차부터 낮은 평가를 받았으며, 특히 D 구의 전체적인 기호도가 저장기간 동안 다른 실험군에 비해 높은 평가를 받았다. 즉, 해양심층수염 을 이용하여 배추를 절임(D)할 경우 천일염이나 정제염에 비해 효과적인 절임이 되어 관능적으로 우수한 평가를 받은 것으로 사료된다. 또한 Shim 등(30)은 기호도가 가장 높은 절임배추의 염도가 $2.8 \%$ 라고 하였는데, 본 연구에서는 $\mathrm{D}$ 구의 염도가 $2.3 \%$ 로 연구결과에 비해 상대적으로 낮은 함 량을 보였으나, 전체적인 기호도 측면에서 $\mathrm{D}$ 구가 다른 실험군에 비해 유의적으로 높은 평가를 받아 Shim 등(30)의 연구결과와 비슷한 경향을 보였다.

\section{무기질}

절임소금의 종류에 따른 절임배추의 저장 0 주차의 무기 질 함량은 Table 2 와 같다. $\mathrm{K}$ 는 $\mathrm{S}, \mathrm{R}, \mathrm{D}$ 구가 각각 245 , $238,257 \mathrm{ppm}$ 이었으며, $\mathrm{CS}, \mathrm{CR}, \mathrm{CD}$ 구는 $232 \mathrm{ppm}, 215$ 
$\mathrm{ppm}, 233 \mathrm{ppm}$ 이었다. $\mathrm{Na}$ 는 $\mathrm{CD}$ 구가 $189 \mathrm{ppm}$ 으로 실험군 중 가장 높았고 $\mathrm{S}, \mathrm{R}, \mathrm{D}$ 구가 각각 $135,138,137 \mathrm{ppm}$ 순으로 높았으며, $\mathrm{CS}$ 구가 $126 \mathrm{ppm}, \mathrm{CR}$ 구 $114 \mathrm{ppm}$ 순으로 나타났 다. $\mathrm{Fe}$ 는 $\mathrm{D}, \mathrm{CR}$ 그리고 $\mathrm{CD}$ 구 모두 $0.8 \mathrm{ppm}$, 그리고 $\mathrm{S}$, $\mathrm{R}, \mathrm{CS}$ 모두 $0.7 \mathrm{ppm}$ 이었다. $\mathrm{Zn}$ 은 $\mathrm{S}, \mathrm{R}, \mathrm{D}$ 각각 $0.5,0.2$, $0.8 \mathrm{ppm}$ 검출되었으며, $\mathrm{CS}, \mathrm{CR}, \mathrm{CD}$ 구는 $0.9,1.0,1.1 \mathrm{ppm}$ 검출되어 실험실 제조군과 시판제품 간의 차이가 있었다. $\mathrm{Mg}$ 은 S, R, D 구가 $0.3,0.1,0.4 \mathrm{ppm}$ 이었으며, $\mathrm{CS}$ 와 $\mathrm{CD}$ 구는 $0.1,0.2 \mathrm{ppm}$ 검출되었다. $\mathrm{CR}$ 구에서는 $\mathrm{Mg}$ 이 검출되지 않았 다. Lee 등(28)은 무 절임시 해양심층수염과 천일염으로 염장했을 때 해양심층수염 절임무에서 더 많은 무기질이 검출되었다고 보고했으며, Ham 등(31)은 고추장을 대조구 와 해양심층수염 처리구로 나누어 무기질을 분석했을 때 $\mathrm{Fe}$ 의 함량은 큰 차이가 없었지만, $\mathrm{K}$ 함량은 해양심층수염 처리구가 더 높았다고 보고했다. 본 연구에서도 실험실제 조군의 해양심층수염 처리구의 칼륨함량이 가장 높았으며, $\mathrm{Fe}$ 함량은 처리구 모두 0.7 0.8 ppm으로 유사한 수준을 보였다.

Table 2. Mineral content of salted-cabbages prepared by various types of salt on initial week.

\begin{tabular}{cccccc} 
& & & & & (unit : ppm) \\
\hline Group $^{1)}$ & $\mathrm{K}$ & $\mathrm{Na}$ & $\mathrm{Fe}$ & $\mathrm{Zn}$ & $\mathrm{Mg}$ \\
\hline $\mathrm{S}$ & 245 & 135 & 0.7 & 0.5 & 0.3 \\
$\mathrm{R}$ & 238 & 138 & 0.7 & 0.2 & 0.1 \\
$\mathrm{D}$ & 257 & 137 & 0.8 & 0.8 & 0.4 \\
$\mathrm{CS}$ & 232 & 126 & 0.7 & 0.9 & 0.1 \\
$\mathrm{CR}$ & 215 & 114 & 0.8 & 1.0 & - \\
$\mathrm{CD}$ & 233 & 189 & 0.8 & 1.1 & 0.2
\end{tabular}

${ }^{1)} \mathrm{S}$ : cabbage brined with sun dried salt; $\mathrm{R}$ : cabbage brined with refined salt; $\mathrm{D}$ : cabbage brined with deep sea water salt; CS : purchased cabbage brined with sun dried salt; CR : purchased cabbage brined with refined salt; CD : purchased cabbage brined with deep sea water salt

유리아미노산

절임소금의 종류에 따른 절임배추의 저장 0주차 유리아 미노산 함량은 Table 3과 같다. 유리아미노산 총량은 $\mathrm{S}$, $\mathrm{R}, \mathrm{D}$ 구가 각각 $344.3,347.0,327.7 \mathrm{mg} \%, \mathrm{CS}, \mathrm{CR}, \mathrm{CD}$ 구가 각각 $344.3,422.1,478.9 \mathrm{mg} \%$ 로 나타났다. S, R, D 및 CS, $\mathrm{CR}, \mathrm{CD}$ 구의 주요 아미노산은 serine, glutamic acid, alanine, valine, GABA, arginine인 것으로 나타났고, 유리아미노산 총량대비 약 $61 \%$ 수준인 것으로 조사되었다. 필수아미노산 인 threonine, valine, methionine, isoleucine, leucine, phenylalanine, lysine의 총량 및 비율은 $\mathrm{S}, \mathrm{R}, \mathrm{D}$ 구 각각 $91.0,90.3,80.2 \mathrm{mg} \%$, 총 유리아미노산 함량대비 비율은 $27.3,26.0,24.5 \%$ 로 해양심층수염 절임배추가 천일염이나 정제염 절임배추에 비해 필수아미노산 함량이 적은 것으로 나타났다. 하지만 시판제품인 $\mathrm{CS}, \mathrm{CR}, \mathrm{CD}$ 구의 필수아미노
산 총량은 각각 $89.2,122.1,110.3 \mathrm{mg} \%$, 총 유리아미노산 함량대비 25.9, 28.9, 23.0\%로 정제염 절임배추의 필수아미 노산 함량이 가장 적은 것으로 나타났다. 비필수아미노산 인 aspartic acid, serine, glutamic acid, glycine, alanine, tyrosine, histidine의 총량 및 비율은 S, R, D 구 각각 176.0 , $188.0,186.8 \mathrm{mg} \%$, 총 유리아미노산 함량대비 비율은 52.8 , $54.2,57.0 \%$ 로 필수아미노산에 비해 두 배 가까이 많았으며, 해양심층수염 절임배추에서 그의 비율이 가장 높은 것으로 확인되었다. 시판제품인 $\mathrm{CS}, \mathrm{CR}, \mathrm{CD}$ 구의 비필수아미노산 의 총량 및 비율은 각각 $152.3,211.2,270.8 \mathrm{mg} \%$, 총 유리아

Table 3. Free amino acid contents of salted-cabbages prepared by various types of salt on initial week.

\begin{tabular}{|c|c|c|c|c|c|c|}
\hline \multirow{2}{*}{ Free amino acid } & \multicolumn{6}{|c|}{ Group $^{1)}$} \\
\hline & $S$ & $\mathrm{R}$ & $\mathrm{D}$ & CS & CR & $\mathrm{CD}$ \\
\hline Phosphoserine & 1.8 & 2.2 & 1.8 & 0.0 & 1.5 & 2.1 \\
\hline Taurine & 0.0 & 0.0 & 0.0 & 0.0 & 0.9 & 0.4 \\
\hline Aspartic acid & 7.1 & 6.2 & 12.9 & 22.4 & 10.0 & 15.4 \\
\hline Threonine & 10.2 & 12.1 & 9.7 & 8.4 & 14.1 & 13.9 \\
\hline Serine & 27.0 & 29.1 & 30.9 & 15.0 & 32.1 & 23.6 \\
\hline Glutamic acid & 54.9 & 61.9 & 51.5 & 26.9 & 69.2 & 107.0 \\
\hline a-amino adipic acid & 0.4 & 0.4 & 0.0 & 0.0 & 0.0 & 0.9 \\
\hline Glycine & 9.1 & 8.8 & 8.9 & 9.2 & 12.4 & 11.6 \\
\hline Alanine & 67.4 & 73.2 & 72.7 & 67.7 & 79.6 & 97.8 \\
\hline Citrlline & 0.0 & 0.0 & 0.0 & 19.3 & 0.0 & 0.0 \\
\hline a-amino-n-butyric acid & 0.4 & 0.3 & 0.0 & 0.0 & 0.6 & 0.5 \\
\hline Valine & 26.2 & 27.8 & 25.4 & 25.5 & 33.4 & 23.7 \\
\hline Methionine & 6.1 & 5.3 & 5.0 & 5.8 & 6.3 & 6.1 \\
\hline Cystathionine & 5.1 & 3.7 & 4.2 & 3.1 & 3.0 & 3.3 \\
\hline Isoleucine & 11.3 & 11.7 & 10.3 & 12.1 & 17.5 & 14.4 \\
\hline Leucine & 15.8 & 14.3 & 11.7 & 15.6 & 19.8 & 17.9 \\
\hline Tyrosine & 5.8 & 3.0 & 3.5 & 5.3 & 3.9 & 7.1 \\
\hline Phenylalanine & 17.1 & 9.4 & 10.5 & 11.6 & 15.3 & 18.6 \\
\hline$\beta$-Alanine & 4.2 & 4.3 & 4.2 & 4.0 & 4.0 & 4.2 \\
\hline$\gamma$-Amino butyric acid & 10.2 & 3.6 & 2.8 & 40.1 & 20.2 & 23.5 \\
\hline Ethanol amine & 2.7 & 3.0 & 2.3 & 2.2 & 2.4 & 3.8 \\
\hline Ammonia & 8.4 & 7.3 & 7.3 & 18.5 & 10.2 & 19.6 \\
\hline Ornithine & 0.9 & 0.5 & 0.4 & 9.8 & 1.3 & 6.2 \\
\hline Lysine & 4.3 & 9.7 & 7.6 & 10.2 & 15.7 & 15.7 \\
\hline Histidine & 4.7 & 5.8 & 6.4 & 5.8 & 4.0 & 8.3 \\
\hline Arginine & 32.0 & 43.5 & 37.8 & 5.8 & 44.5 & 33.1 \\
\hline Total & 301.1 & 303.6 & 290 & 338.5 & 377.4 & 445.6 \\
\hline
\end{tabular}

${ }^{1)} \mathrm{S}$ : cabbage brined with sun dried salt; $\mathrm{R}$ : cabbage brined with refined salt; $\mathrm{D}$ : cabbage brined with deep sea water salt; CS : purchased cabbage brined with sun dried salt; CR : purchased cabbage brined with refined salt; CD : purchased cabbage brined with deep sea water salt 
Table 4. Organic acid content of salted-cabbages prepared by various types of salt on initial week.

\begin{tabular}{ccccccccc} 
(unit : mg\%) \\
\hline Group $^{1)}$ & Tartaric acid & Malic acid & Lactic acid & Acetic acid & Citric acid & Succinic acid & Fumaric acid & Propionic acid \\
\hline S & - & 61 & 21 & - & 126 & 14 & 2 & 65 \\
R & - & 64 & 25 & - & 29 & 20 & - & 85 \\
D & - & 59 & 25 & - & 70 & 20 & - & 49 \\
CS & 148 & 108 & 49 & 40 & 171 & 21 & 52 & 49 \\
CR & 169 & 65 & 41 & - & 207 & 19 & 52 & 57 \\
CD & 267 & - & 48 & - & 428 & 19 & - & - \\
\hline
\end{tabular}

${ }^{1)} \mathrm{S}$ : cabbage brined with sun dried salt; R : cabbage brined with refined salt; D : cabbage brined with deep sea water salt; CS : purchased cabbage brined with sun dried salt; $C R$ : purchased cabbage brined with refined salt; $C D$ : purchased cabbage brined with deep sea water salt

Table 5. Changes in outer-apperence of salted-cabbages prepared by various types of salt during the storage period.

\begin{tabular}{cccccc}
\hline \multirow{2}{*}{ Group $^{1)}$} & \multicolumn{5}{c}{ Storage time (weeks) } \\
\cline { 2 - 6 } & 0 & 1 & 2 & 3 & 4 \\
\hline $\mathrm{S}$ & $5.0 \pm 0.0^{\mathrm{A} 22 \mathrm{a} 3)}$ & $4.3 \pm 0.3^{\mathrm{Bb}}$ & $4.1 \pm 0.9^{\mathrm{Bb}}$ & $3.6 \pm 1.5^{\mathrm{Bc}}$ & $3.2 \pm 0.4^{\mathrm{Bd}}$ \\
$\mathrm{R}$ & $5.0 \pm 0.0^{\mathrm{Aa}}$ & $4.2 \pm 0.5^{\mathrm{Cb}}$ & $4.0 \pm 0.4^{\mathrm{Cc}}$ & $3.4 \pm 1.4^{\mathrm{Cd}}$ & $3.2 \pm 0.5^{\mathrm{Be}}$ \\
$\mathrm{D}$ & $5.0 \pm 0.0^{\mathrm{Aa}}$ & $4.5 \pm 0.5^{\mathrm{Ab}}$ & $4.3 \pm 1.1^{\mathrm{Ab}}$ & $3.8 \pm 1.6^{\mathrm{Ac}}$ & $3.3 \pm 0.6^{\mathrm{Ad}}$ \\
$\mathrm{CS}$ & $5.0 \pm 0.0^{\mathrm{Aa}}$ & $4.5 \pm 0.6^{\mathrm{Ab}}$ & $4.1 \pm 1.3^{\mathrm{Bc}}$ & $3.4 \pm 1.6^{\mathrm{Cd}}$ & $3.0 \pm 1.5^{\mathrm{Ce}}$ \\
$\mathrm{CR}$ & $5.0 \pm 0.0^{\mathrm{Aa}}$ & $4.1 \pm 0.4^{\mathrm{Db}}$ & $3.4 \pm 0.5^{\mathrm{Dc}}$ & $2.8 \pm 0.5^{\mathrm{Dd}}$ & $2.6 \pm 1.3^{\mathrm{De}}$ \\
$\mathrm{CD}$ & $5.0 \pm 0.0^{\mathrm{Aa}}$ & $4.0 \pm 0.8^{\mathrm{DEb}}$ & $3.4 \pm 1.6^{\mathrm{Dc}}$ & $3.4 \pm 0.8^{\mathrm{Cc}}$ & $3.0 \pm 1.5^{\mathrm{Cd}}$ \\
\hline
\end{tabular}

${ }^{1)} \mathrm{S}$ : cabbage brined with sun dried salt; $\mathrm{R}$ : cabbage brined with refined salt; D : cabbage brined with deep sea water salt; CS : purchased cabbage brined with sun dried salt; CR : purchased cabbage brined with refined salt; CD : purchased cabbage brined with deep sea water salt

${ }^{2}$ Means with different letters (A-F) between the different treatments differ significantly $(\mathrm{p}<0.05)$.

${ }^{3}$ Means with different letters (a-e) between the different storage time differ significantly $(\mathrm{p}<0.05)$.

Table 6. Changes in sourness of salted-cabbages prepared by various types of salt during the storage period.

\begin{tabular}{cccccc}
\hline \multirow{2}{*}{ Group $^{1)}$} & \multicolumn{5}{c}{ Storage time (weeks) } \\
\cline { 2 - 6 } & 0 & 1 & 2 & 3 & 4 \\
\hline $\mathrm{S}$ & $5.0 \pm 0.0^{\mathrm{A} 2 \mathrm{a} 3)}$ & $4.2 \pm 0.5^{\mathrm{ABb}}$ & $3.8 \pm 0.5^{\mathrm{Ac}}$ & $3.2 \pm 0.4^{\mathrm{Ad}}$ & $3.0 \pm 1.0^{\mathrm{Ad}}$ \\
$\mathrm{R}$ & $5.0 \pm 0.0^{\mathrm{Aa}}$ & $4.1 \pm 0.6^{\mathrm{BCb}}$ & $3.5 \pm 0.5^{\mathrm{Bc}}$ & $3.0 \pm 0.5^{\mathrm{Bd}}$ & $2.8 \pm 1.0^{\mathrm{Cd}}$ \\
$\mathrm{D}$ & $5.0 \pm 0.0^{\mathrm{Aa}}$ & $4.3 \pm 0.5^{\mathrm{Ab}}$ & $3.8 \pm 0.7^{\mathrm{Ac}}$ & $3.3 \pm 1.0^{\mathrm{Ad}}$ & $3.0 \pm 0.5^{\mathrm{Ae}}$ \\
$\mathrm{CS}$ & $5.0 \pm 0.0^{\mathrm{Aa}}$ & $4.0 \pm 0.5^{\mathrm{Cb}}$ & $3.4 \pm 0.5^{\mathrm{Bc}}$ & $3.2 \pm 0.5^{\mathrm{Ac}}$ & $2.9 \pm 0.5^{\mathrm{Bd}}$ \\
$\mathrm{CR}$ & $5.0 \pm 0.0^{\mathrm{Aa}}$ & $4.0 \pm 0.7^{\mathrm{Cb}}$ & $3.0 \pm 0.9^{\mathrm{Cc}}$ & $2.8 \pm 0.6^{\mathrm{Cd}}$ & $2.6 \pm 1.0^{\mathrm{Dd}}$ \\
$\mathrm{CD}$ & $5.0 \pm 0.0^{\mathrm{Aa}}$ & $4.2 \pm 0.6^{\mathrm{ABb}}$ & $3.4 \pm 1.0^{\mathrm{Bc}}$ & $3.3 \pm 0.5^{\mathrm{Ac}}$ & $3.0 \pm 0.5^{\mathrm{Ad}}$ \\
\hline
\end{tabular}

${ }^{1)} \mathrm{S}$ : cabbage brined with sun dried salt; $\mathrm{R}$ : cabbage brined with refined salt; $\mathrm{D}$ : cabbage brined with deep sea water salt; CS : purchased cabbage brined with sun dried salt; CR : purchased cabbage brined with refined salt; CD : purchased cabbage brined with deep sea water salt

${ }^{2}$ Means with different letters (A-F) between the different treatments differ significantly $(\mathrm{p}<0.05)$.

${ }^{3}$ Means with different letters (ae) between the different storage time differ significantly $(\mathrm{p}<0.05)$.
Table 7. Changes in overall acceptance of salted-cabbages prepared by various types of salt during the storage period.

\begin{tabular}{cccccc}
\hline \multirow{2}{*}{ Group $^{1)}$} & \multicolumn{5}{c}{ Storage time (weeks) } \\
\cline { 2 - 6 } & 0 & 1 & 2 & 3 & 4 \\
\hline $\mathrm{S}$ & $\left.5.0 \pm 0.0^{\mathrm{Az}) \mathrm{a} 3}\right)$ & $4.2 \pm 0.4^{\mathrm{Bb}}$ & $3.8 \pm 1.1^{\mathrm{Ac}}$ & $3.2 \pm 0.4^{\mathrm{Ad}}$ & $3.0 \pm 0.4^{\mathrm{Ae}}$ \\
$\mathrm{R}$ & $5.0 \pm 0.0^{\mathrm{Aa}}$ & $4.1 \pm 0.5^{\mathrm{Cb}}$ & $3.5 \pm 0.5^{\mathrm{Bc}}$ & $3.0 \pm 0.5^{\mathrm{Bd}}$ & $2.8 \pm 0.5^{\mathrm{Bd}}$ \\
$\mathrm{D}$ & $5.0 \pm 0.0^{\mathrm{Aa}}$ & $4.3 \pm 0.5^{\mathrm{Ab}}$ & $3.8 \pm 0.5^{\mathrm{Ac}}$ & $3.3 \pm 0.4^{\mathrm{Ad}}$ & $3.0 \pm 0.6^{\mathrm{Ae}}$ \\
$\mathrm{CS}$ & $5.0 \pm 0.0^{\mathrm{Aa}}$ & $4.0 \pm 1.0^{\mathrm{Db}}$ & $3.4 \pm 0.6^{\mathrm{Bc}}$ & $3.2 \pm 0.6^{\mathrm{Ac}}$ & $2.9 \pm 0.5^{\mathrm{Ad}}$ \\
$\mathrm{CR}$ & $5.0 \pm 0.0^{\mathrm{Aa}}$ & $4.0 \pm 0.6^{\mathrm{Db}}$ & $3.0 \pm 0.5^{\mathrm{Cc}}$ & $2.8 \pm 1.0^{\mathrm{Cd}}$ & $2.6 \pm 1.0^{\mathrm{Ce}}$ \\
$\mathrm{CD}$ & $5.0 \pm 0.0^{\mathrm{Aa}}$ & $4.2 \pm 0.5^{\mathrm{Bb}}$ & $3.4 \pm 0.8^{\mathrm{Bc}}$ & $3.3 \pm 1.2^{\mathrm{Ac}}$ & $3.0 \pm 0.5^{\mathrm{Ad}}$ \\
\hline
\end{tabular}

${ }^{1)} \mathrm{S}$ : cabbage brined with sun dried salt; $\mathrm{R}$ : cabbage brined with refined salt; $\mathrm{D}$ cabbage brined with deep sea water salt; CS : purchased cabbage brined with sun dried salt; $\mathrm{CR}$ : purchased cabbage brined with refined salt; $\mathrm{CD}$ : purchased cabbage brined with deep sea water salt

${ }^{2}$ Means with different letters (A-F) between the different treatments differ significantly $(\mathrm{p}<0.05)$.

${ }^{3}$ Means with different letters (a-e) between the different storage time differ significantly $(\mathrm{p}<0.05)$.

미노산 함량대비 비율은 44.2, 50.1, 56.6\%로 실험실 제조군 과 마찬가지로 해양심층수염 절임배추의 비필수아미노산 의 비율이 가장 높았으며, 그의 함량 또한 정제염이나 천일 염 절임배추에 비해 높은 것으로 나타났다.

\section{유기산}

절임소금의 종류에 따른 절임배추의 저장 0 주차 유기산 함량은 Table 4와 같다. 유기산함량 분석법상 무수물 기준 으로 분석되었다. Tartaric acid는 S, R, D 구에서는 검출되지 않은 반면, $\mathrm{CS}, \mathrm{CR}, \mathrm{CD}$ 구에서 각각 $148,169,267 \mathrm{mg} \%$ 로 검출되었다. Malic acid는 $\mathrm{CD}$ 구를 제외한 나머지 실험군에 서 검출되었는데, $\mathrm{CS}$ 군이 $108 \mathrm{mg} \%$ 으로 가장 높았고, $\mathrm{CR}$, $\mathrm{R}, \mathrm{S}, \mathrm{D}$ 구 순으로 낮았다. $\mathrm{pH}$, 산도 및 유산균 성장과 관련 된 lactic acid 함량은 $\mathrm{S}, \mathrm{R}, \mathrm{D}$ 구가 $20 \sim 25 \mathrm{mg} \%$ 였으며 $\mathrm{CS}$, $\mathrm{CR}, \mathrm{CD}$ 구는 41 49 mg\%였다. Acetic acid는 CS 구에서만 $40 \mathrm{mg} \%$ 가 검출되었다. Citric acid는 $\mathrm{CD}$ 구가 $428 \mathrm{mg} \%$ 으로 실험군 중 가장 높았고, S 구가 $126 \mathrm{mg} \%, \mathrm{CR}(207 \mathrm{mg} \%)$, CS, S, D, R 순으로 낮게 나타났다. Succinic acid는 CS 구가 
$21 \mathrm{mg} \%$ 로 실험군 중 가장 높았고, $\mathrm{S}$ 구가 $14 \mathrm{mg} \%$ 로 유의적 으로 가장 적었으며, $\mathrm{R}$ 과 $\mathrm{D}$ 구가 모두 $20 \mathrm{mg} \%, \mathrm{CS}, \mathrm{CR}$, $\mathrm{CD}$ 구가 각각 $21,19,19 \mathrm{mg} \%$ 로 조사되었다. Fumaric acid는 $\mathrm{CS}$ 와 $\mathrm{CS}$ 구가 모두 $52 \mathrm{mg} \%$ 으로 실험군 중 가장 높았고, $\mathrm{S}$ 구가 $2 \mathrm{mg} \%$ 로 가장 낮았으며, $\mathrm{R}, \mathrm{D}, \mathrm{CD}$ 구에서는 검출되지 않았다. Propionic acid는 R 구가 $85 \mathrm{mg} \%$ 로 실험 군 중 가장 많았고, $\mathrm{D}$ 구가 $49 \mathrm{mg} \%$ 로 가장 적었으며, $\mathrm{S}$, $\mathrm{CR}, \mathrm{D}, \mathrm{CS}$ 구 순으로 적었다. $\mathrm{CD}$ 구에서는 propionic acid가 검출되지 않았다. 유기산 함량 분석결과, 절임소금의 종류 에 따른 차이는 명확히 나타나지 않았으며, 시판제품 중 해양심층수염 절임배추에서 tartaric acid와 citric acid가 정 제염이나 천일염 처리구에 비해 다량 함유 된 것으로 확인 되었다.

\section{요 약}

본 연구에서는 천일염, 정제염, 해양심층수염을 사용하 여 제조한 절임배추의 냉장저장 $\left(0^{\circ} \mathrm{C}\right)$ 중 품질변화 및 시판 제품과의 품질특성을 비교 조사하였다. $\mathrm{pH}$ 의 경우 저장기 간 전반적으로 $\mathrm{S}, \mathrm{R}, \mathrm{D}$ 구가 $\mathrm{CS}, \mathrm{CR}, \mathrm{CD}$ 구에 비해 높았고, 적정산도는 저장기간 전반적으로 $\mathrm{CS}, \mathrm{CR}, \mathrm{CD}$ 구가 $\mathrm{S}, \mathrm{R}$, $\mathrm{D}$ 구에 비해 높았다. 수분함량은 저장기간이 경과할수록 삼투압 작용에 의하여 모든 실험군에서 감소하였고, 염도 는 $\mathrm{S}, \mathrm{R}, \mathrm{D}$ 구가 $2.0 \sim 2.6 \%$ 로 $\mathrm{CS}, \mathrm{CR}, \mathrm{CD}$ 구(0.9 1.8\%)에 비해 저장기간 동안 유의적으로 높았다. 총균수 및 유산균 수는 $\mathrm{CS}, \mathrm{CR}, \mathrm{CD}$ 구가 저장 1 주 이후부터 급격히 증가하여 저장기간 동안 $\mathrm{S}, \mathrm{R}, \mathrm{D}$ 구에 비해 유의적으로 높게 나타나 $\mathrm{pH}$ 및 적정산도의 변화에 영향을 주었다. 경도와 씸힘성의 경우 모든 실험군에서 저장기간이 경과함에 따라 감소하였 고 저장기간 동안 해양심층수염으로 제조한 절임배추(D) 의 경도가 다른 실험군에 비해 유의적으로 높게 나타났다. 유리아미노산 총량은 $\mathrm{CD}$ 구가 가장 높았고 $\mathrm{D}$ 구가 가장 낮았으며, 필수아미노산의 비율은 소금의 종류에 따른 큰 차이를 보이지 않았지만, 비필수아미노산의 비율은 해양심 층수염으로 제조 된 시판제품이 가장 높았다. 유기산 총량 은 $\mathrm{CD}$ 구가 가장 높았고 해양심층수염으로 제조한 $\mathrm{D}$ 와 정제염으로 제조한 $\mathrm{R}$ 구가 가장 낮았다. 무기질 총함량의 경우에도 $\mathrm{CD}$ 구가 실험군 중 가장 높았고, $\mathrm{D}, \mathrm{S}, \mathrm{R}, \mathrm{CR}$, $\mathrm{CS}$ 순으로 낮게 나타났다. $\mathrm{K}$ 와 $\mathrm{Mg}$ 함량은 해양심층수염으 로 제조한 $\mathrm{D}$ 구가 실험군 중 가장 높았고, $\mathrm{Na}$ 함량은 $\mathrm{CD}$ 구가 가장 높았다. 관능적 외관, 산미 및 전체적 기호도는 모든 실험군에서 저장기간이 경과함에 따라 감소하였으나 해양심층수염으로 제조한 절임배추(D)의 외관, 산미 및 전 체적 기호도는 저장기간 동안 다른 실험군에 비해 유의적으 로 높은 평가를 받았다. 즉, 해양심층수염으로 절임배추를 제조할 경우 천일염이나 정제염으로 절임한 배추에 비해
관능적으로 우수하고 무기질, 유기산 함량이 높은 양질의 절임배추를 제조할 수 있을 것으로 사료되었다.

\section{감사의 글}

본 연구는 강릉농협 용역기술개발(I01920) 연구비 지원 에 의해 이루어진 것이며, 이에 감사드립니다.

\section{References}

1. Hwang ES (2010) Changes in myrosinase activity and total glucosinolate levels in Korean chinese cabbage by salting conditions. Korean J Food Cookery Sci, 26, 104-109

2. Park SS, Sung JM, Jeong JW, Park KJ, Lim JH (2013) Quality changes of salted chinese cabbage with electrolyzed water washing and a low storage temperature. J Korean Soc Food Sci Nutr, 42, 615-620

3. Shin JH, Kim RJ, Kang MJ, Kim GM, Sung NJ (2012) Quality and fermentation characteristics of garlic-added kimchi. Korean J Food Preserv, 19, 539-546

4. Hwang JH (2002) Antioxidative activities of anthocyanins from red leaf mustard (Brassica juncea Coss. var. integrifolia). MS Thesis, Pusan National University, Pusan, Korea

5. Han ES, Seok MS (1996) Improvement of salting process of chinese cabbage in kimchi factory. Food Industry Nutr, $1,50-70$

6. Kim YW, Jeong JK, Lee SM, Kang SA, Lee DS, Lim SH, Park KY (2009) Effect of permeability-controlled polyethylene film on extension of shelf-life of brined Baechu. J Korean Soc Food Sci Nutr, 38, 1767-1772

7. Kim JB, Yoo MS, Cho HY, Choi DW, Pyun YR (1990) Changes in physical characteristics of chinese cabbage during salting and blanching. Korean J Food Sci Technol, 22, 445-450

8. Kim HO, Suh SR, Choi YS, Yoo SN, Kim YT (2007) Optimal conditions for mechanized salting process of salt-inserting method for winter cabbage to produce Kimchi. Korean J Food Preserv, 14, 695-701

9. Ha JO, Park KY (1998) Comparison of mineral contents and external structure of various salts. J Korean Soc Food Sci Nutr, 27, 413-418

10. Lee GD, Kim SK, Kim JO, Kim ML (2003) Comparison of quality characteristics of salted muskmelon with deep 
sea water salt, sun-dried and purified salts. J Korean Soc Food Sci Nutr, 32, 840-846

11. Han SS, Kim SH, Yoo SJ, Oh HT, Choi HJ, Chung MJ (2008) Biological activities of soybean sauce (Kanjang) supplemented with deep sea water and sea tangle. Korean J Food Preserv, 15, 274-279

12. Park WP (2004) Quality characteristics of salted chinese cabbage treated with electrolyzed-acid water during storage. Korean J Food Sci Technol, 36, 365-367

13. Lee JS, Park SH, Lee YS, Lim BS, Yim SC, Chun, CH (2008) Characteristics of growth and salting of chinese cabbage after spring culture analyzed by cultivar and cultivation method. Korean J Food Preserv, 15, 43-48

14. Han ES, Seok MS, Park JH (1998) Quality changes of salted Baechu with packaging methods during long term storage. Korean J Food Sci Technol, 30, 1307-1311

15. Kim JH, Park KY, Choi HS, Yang JY (2010) Quality evaluations of conventional salted cabbages. Korean $\mathbf{J}$ Food Nutr, 23, 659-663

16. AOAC (1995) Official Methods of Analysis 16th ed. Association of official Analytical Chemists, Washington DC, p 69-74

17. Doughty HW (1924) Mohr's method for the determination of silver and halogens in other than neutral solutions. J Am Chem Soc, 46, 2707-2709

18. Korean Food and Drug administration (2002) Korea Food Code. Moonyung-Sa. Seoul, Korea, p 643-647

19. Kim SJ, Kim HL, Ham KS (2005) Characterization of kimchi fermentation prepared with various salts. Korean J Food Preserv, 12, 395-104

20. Kim YW, Jung JK, Cho YJ, Lee SJ, Kim SH, Park KY, Kang SA (2009) Quality changes in brined baechu cabbage using different types of polyethylene film, and salt content during storage. Korean J Food Preserv, 16, 605-611

21. Lee IS, Park WS, Koo YJ, Kang KH (1994) Changes in some characteristics of brined chinese cabbage of fall cultivars during storage. Korean J Food Sci Technol, 26, 239-245

22. Park WS, Lee IS, Han YS, Koo YJ (1994) Kimchi preperation with brined chinese cabbage and seasoning mixture stored separately. Korean J Food Sci Technol, 26, 231-238

23. Kim JG, Choi HS, Kim SS, Kim WJ (1989) Changes in physicochemical and sensory qualities of Korean pickled cucumbers during fermentation. Korean J Food Sci Technol, 21, 838-844

24. Han ES, Seok MS, Park JH (1998) Changes of characteristics in salted Baechu (Chinese cabbage) and its exudate during long term storage. Korean J Postharv Sci Technol, 5, 165-169

25. Koh HK, Lee H, Yang HC (1993) Quality changes of salted chinese cabbage and kimchi during freezing storage. Korean Soc Food Sci Nutr, 22, 62-67

26. Jeong JK, Park SE, Lee SM, Choi HS, Kim SH, Park KY (2011) Quality changes of brined baechu cabbage prepared with low temperature stored baechu cabbages. J Korean Soc Food Sci Nutr, 40, 475-479

27. Lee MH, Lee GD, Son KJ, Yoon SR, Kim JS, Kwon JH (2002) Changes in organoleptic and rheological properties of chinese cabbage with salting condition. J Korean Soc Food Sci Nutr, 31, 417-422

28. Lee GD, Kim SK, Lee HA, Lee MH, Kim ML (2003) Changes of quality characteristics of radishes salted with deep seawater salt. Korean J Food Preserv, 10, 182-186

29. Kim SD, Park HD, Kim MK (1997) Morphological characteristics and composition of cell wall polysaccharides of Brassica campestris var. perkinensis (baechu). Korean J Post-Harvest Sci Technol Agri Products, 4, 301-309

30. Shim YH, Ahn GJ, Yoo CH (2003) Characterization of salted chinese cabbage in relation to salt content, temperature and time. Korean J Food Cookery Sci, 19, 210-215

31. Ham SS, Kim SH, Yoo SJ, Oh HT, Choi HJ, Chung MJ (2008) Quality characteristics of Kochujang added deep sea water salt and sea tangle. Korean J Food Preserv, 15, 214-218

(접수 2014년 6월 9일 수정 2014년 8월 10일 채택 2014년 8월 21일) 